\title{
Streambed Pollution: A comprehensive review of its sources, eco-hydro-geo-chemical impacts, assessment, and mitigation strategies
}

\author{
Aadhityaa Mohanavelu $^{1 *}$, Shivansh Shrivastava ${ }^{2}$, and Sujay Raghavendra Naganna ${ }^{3}$
}

\begin{abstract}
Streambeds are an integral component of the river ecosystems. It provides habitat for a vast array of benthic and aquatic organisms as well as facilitate for the bio-degradation and transformation of organic matter and other nutrients. Increasing anthropogenic influence introduces multiple stressors to the stream networks resulting in pollution of streambeds, which in turn, could have detrimental effects on overall stream ecosystem health. There are gaps in the current understanding of the impacts of streambed pollution and the mitigation strategies lack holistic approach. In this review, we first present a global inventory to highlight the status of streambed pollution around the globe. Next, we synthesize the state-of-art knowledge of conventional and emerging forms of contaminants, their overall impacts on stream ecosystem functions, and finally present future directions to comprehend the problem of streambed pollution. We highlight that fine sediments and plastics (found especially in urban streambeds) are among the major physical pollutants causing streambed pollution and the chemical pollutants generally comprise of hydrophobic compounds including various legacy contaminants such as polychlorinated biphenyl (PCB), dichlorodiphenyltrichloroethane (DDT), a wide range of pesticides and a variety of heavy metals. Further, in recent years, highly polar and hydrophilic emerging contaminants such as micro-plastics, pharmaceutical waste and personal care products have been identified in riverbeds around the world. We stress that the impacts of streambed pollution have been largely studied with discipline-driven perspectives amongst which the ecological impacts have received a lot of attention in the past. To present a comprehensive outlook, this review also synthesizes the hydrological, geomorphological and biochemical impacts of different forms of streambed pollution. In the end, we endorse the positive and negative aspects of the current impact assessment methodologies and also highlight various physical, chemical and biological remediation measures that could be applied to alleviate streambed pollution.
\end{abstract}

\section{Keywords}

Streambed pollution; Global pollution inventory; Emerging contaminants; Stream pollutants; Eco-hydro-geo-chemical impacts; Pollution mitigation and remediation

${ }^{1}$ Department of Water Science and Engineering, UNESCO-IHE, Westvest 7, 261 1, AX, Delft, The Netherlands.

${ }^{2}$ Environmental Hydrology and Water Resources Croup, Department of Infrastructure Engineering, The University of Melbourne, Parkville, UIC, 3010 , Australia.

${ }^{3}$ Department of Civil Engineering, Siddaganga Institute of Technology, Tumakuru 572 103, Karnataka, India.

*Corresponding author: aadhityaa65@gmail.com

\section{Contents}

1 Introduction

2 Global Inventory of Streambed Pollution

3 Types of Streambed Pollutants and Sources

3.1 Physical ................. 4

3.2 Chemical . . . . . . . . . . . . . . 4

3.3 Biological or Microbial . . . . . . . . . . . 4

4 Impacts of Streambed Pollution 4

4.1 Hydrological Impacts . . . . . . . . . . . . . 4

4.2 Ecological Impacts . . . . . . . . . . . . 5

4.3 Geomorphological Impacts . . . . . . . . . . . 6

4.4 Biochemical Impacts . . . . . . . . . . . 7
5 Impact Assessment Methodologies: Pros and Cons 7

6 Mitigation and Remediation Strategies 9

6.1 Physical Measures . . . . . . . . . . . . . . . 9

6.2 Chemical and Biotechnological Measures ....... . 9

7 Conclusions

\section{Introduction}

Streams are important surface water resource systems that support diverse aquatic and riparian life-forms, transport sediments and nutrients, and provide several services relevant to human civilization such as drinking and irrigation water supplies and hydro-power generation $[1,2,3]$. However, with growing urbanization and industrialization, pollution of stream ecosystems has emerged as one of the world's greatest chal- 
lenges $[4,5,6]$. Stream pollution is caused by a wide range of contaminants reaching river systems from a variety of natural and anthropogenic sources. For instance, pollutants such as fine sediments, pesticides, plastics, chemicals and biological wastes from industrial effluents and urban discharge are being detected in streams across the world [7, 8]. Once the stream water gets contaminated, the contaminants may accumulate over the underlying sediments and remain within the streambeds for years, even after they become untraceable in the surface water, hence making streambeds a potential reservoir of contaminants $[9,10,11,12]$.

Streambed pollutants could be divided into three categories - physical, chemical, and biological. Physical pollutants like excessive fine sediments (size $\leq 2 \mathrm{~mm}$ diameter) in the surface water are the major source of streambed pollution $[13,14,15,16,17]$. Fine sediment pollution could also facilitate secondary pollution. For example, heavy metals and many other hydrophobic compounds adhere to the surface of the fine sediment and persist for a longer time [18, 19]. A wide array of chemical pollutants ranging from toxic halogenated compounds to metals have also been known to pollute the streambeds [20, 21, 22]. For instance, pesticides which are widely used in agriculture are the most commonly identified streambed pollutants that include many legacy chemicals such as dichlorodiphenyltrichloroethane (DDT), polychlorinated bipheny (PCB), and chlordane [23, 24, 25]. Additionally, streambed contamination contributed from urban sources via natural runoff are usually associated with heavy metals and oil based contaminants (polycyclic aromatic hydrocarbons) transported from vehicular emissions, sewage and industrial releases [26, 27]. Further, a new class of chemical pollutants labelled as emerging contaminants which includes micro-plastics, personalcare products and pharmaceutical compounds are being observed in streambeds, and are proven to cause detrimental health risks to humans as well as to the fluvial ecosystems $[28,29,30]$. Some biological pollutants like Escherichia coli and Coliform, also have a profound impact on the microbial quality of stream water [31]. Recent studies indicate that these biological pollutants could persist more effectively near the streambed surface than in the dissolved water and have adverse effects on benthic organisms [32].

While the physical, chemical and biological contamination of streambeds have multi-faceted implications on the overall functioning of stream ecosystems, major attention has been garnered to the study of associated ecological impacts and consequently the hydrological, geological and biochemical impacts of streambed pollution are relatively lessstudied. Previous studies related to streambed pollution have focused particularly on the assessment methods gauging the ecological risks of streambed pollution, and identification and characterization of specific pollutants such as heavy metals and pesticides in the streambed [26, 33]. Understanding the hydro-bio-geo-chemical implications of streambed pollution is important for managing stream ecosystems, particularly with increasing anthropogenic pollution $[34,35]$. There is need for studying streambed pollution in a broader scope and develop more comprehensive monitoring and mitigation strategies to conserve the stream ecosystems. In this review, we succinctly present the state-of-art knowledge about the different forms of streambed pollution and their subsequent influence on the hydrology, geomorphology, bio-geochemistry and ecology of stream ecosystems. We present an overview of the current inventory of streambed pollution studies at global level and evaluate the complexity and relevance of different impact assessment methodologies that have been adopted in the past and highlight their shortcomings. Finally, we present some effective remediation measures and mitigation strategies which would enable more comprehensive and successful management of streambed pollution.

\section{Global Inventory of Streambed Pollution}

Extensive research on the characterization of streambed pollution in rivers and estuaries have been carried out in the United States of America (USA) over the past decades through various national programs [24, 36, 37, 38, 39, 40, 41]. Fine sediment pollution is most common streambed pollutant in the USA and causes $\$ 16$ billion in environmental damage annually [42]. Streambed sediment surveys in Forth Worth and Bexar County near Texas, USA have found strong relationships between the land use and selected pollutant (hydrophobic organic contaminants and heavy metals) concentrations within the streambed sediments [43, 44]. A comprehensive study on assessing the influence of fine sediment pollution on the streambed ecosystem in the Midwestern United States (in about 83 stream reaches) concluded that it is not plausible to reduce or control fine sediment pollution and the retention of coarser sediments in the streambed is the only alternate management strategy to control fine sediment pollution in the region [45]. In the lower Mississippi River of USA, a meticulous study of age-dated sediment core samples revealed an upward trend in the concentration of hydrophobic organic compounds (except PAH) and trace elements in the streambed from the 1930's to 1970's followed by a decreasing trend till 2012 [46]. Several large scale programs in the USA have attempted to study the occurrence, distribution and trends of pesticides in streambeds, however, these studies vary widely in terms of sample collection methods, analysis of sediment-cores and the species of biota sampled [36, 47, 48, 49, 50, 51]. The major shortcomings of the studies in the USA is the complexity in deriving an overall assessment of streambed pollution at a provincial or national scale, which can be mainly attributed to the differences in the design and duration of these studies [24]. According to the estimates of US Environmental Protection Agency (EPA), about 10\% of the sediments under surface waters in USA are contaminated with potential toxic pollutants and in about 96 out of 1,372 watersheds studied (from 2,111 watersheds in USA); potential adverse effects were evident on the aquatic biota and human life caused by streambed pollution [52]. 
In the Europe, extensive research on the assessment of streambed pollution started much later than the USA, under the EU Water Framework Directive (WFD) and European Sediment Research Network (SedNet) [53, 54]. SedNet has initiated streambed sediment monitoring at river basin scale with a prime objective of progressive reduction of the contamination caused by priority substances to attain 'no-deterioration' condition [54, 55]. According to an assessment by SedNet in 2009, about 200 million cubic meters of fine sediments in streambeds were dredged in the EU of which the contaminated polluted sediments were treated using ex-situ treatment techniques after being dumped at large landfill sites by employing special facilities [56]. SEDI.PORT.SIL. was one such successful project undertaken in the EU with an intention to manage and transform about $98 \%$ of the dredged contaminated streambed sediments into marketable products [57]. However, unlike the USA, only a limited number of studies on streambed pollution are available in the EU. One such study attempted in several Danish lowland streams discovered considerable concentrations of pesticides and heavy metals in the streambed sediments [58]. In Gasconge region of France, enrichment of several heavy metals including Copper, Lead, Cobalt and Zinc have been reported in both the forested and in the downstream of the cultivated catchments caused by the deposition of industrial and petrochemical combustions and fertilizer usage, respectively in the upstream regions [59].

Literature evidences indicate that South America is underrepresented in streambed pollution studies. A recent study in the Magdalena River located in the Colombian Caribbean area documents various forms of anthropogenic pollution of streambeds and the identified pollutants include hazardous chemical traces and fine sediment pollution [60]. In Brazil, contaminated streambed sediments with heavy metals such as $\mathrm{Zn}$ and $\mathrm{Hg}$, and emerging contaminants such as diclofenac, ciprofloxacin and erythromycin have been detected [61, 62, 63]. Further, arsenic and other heavy metals like $\mathrm{As}, \mathrm{Pb}$ and $\mathrm{Cu}$ have been identified in stream sediments near mining sites in Mexico [64]. Similarly, in Australia some instances of streambed pollution by heavy metals and other emerging contaminants near mining sites have been documented $[65,66]$. A recent study by Wright et al. 2018 [66] reveals that leaching of minerals from concrete (of storm water drainage infrastructure) is causing a new type of pollution in urban streambeds.

The problem of streambed pollution in rest of the world is perhaps even more worse. The presence of pollutants in streambeds have been extensively reported throughout China of which metallic and chemical contaminants are majorly spotted at acute levels $[67,68,69,70]$. Several studies in the Yangtze River (one of the major rivers of China) and its tributaries report high levels of heavy metal pollution in its streambeds and this trend was consistent with the rapid industrial and urban development in the region [71, 72]. Analysis of sedimentary cores taken from Mianjiang river estuary, a tributary of upper Yangtze river, China, have shown drastic increase in lead concentration levels from $6 \%$ in the year 1950 to $23.7 \%$ in 2010 [72]. Similarly, in the Three Gorges Dam, having the biggest reservoir along the Yangtze River, high levels of heavy metals accumulation were found in the water-level-fluctuation zones due to increased shipping and industrial wastes discharged into the reservoir bed [71, 73]. In India, streambed pollution has not been extensively studied yet, however, there are few studies which report streambed pollution near mining sites $[74,75,76]$. A study in South Korea's Shihwa stream using isotopic methods found high streambed pollution by organic matter constituted mainly by industrial discharge in the catchment area [77]. An assessment of streambed sediment contamination by heavy metals in the Gabes catchment of south-eastern Tunisia, revealed high degree of contamination especially near to the urban and industrial hubs of the Gabes city [34]. However, the accumulation of heavy metals in toxic amounts, was not observed in the streambed sediments of Orogodo River in southern Nigeria based on analysis using multiple pollution indices [78]. In Iran, streambed sediment pollution by trace elements including Iron ( $\mathrm{Fe}$ ), Manganese $(\mathrm{Mn})$, Mercury ( $\mathrm{Hg})$, Cadmium (Cd), Copper (Cu), Chromium $(\mathrm{Cr})$, Nickel $(\mathrm{Ni})$, Lead $(\mathrm{Pb})$, and $\mathrm{Zinc}(\mathrm{Zn})$ has been documented in South Eastern and Eastern parts of Iran with evidence that geological factors control the extent of streambed pollution in the region $[79,80]$.

The current global trends suggest that although strembed pollution have been adequately investigated in some regions of the world, its understanding (in terms of the extent of impacts and hazards), monitoring, and control/mitigation are still very limited across the globe. It is also evident that only certain type of streambed pollution, notably heavy metal and fine sediment, have been widely documented while pesticides, industrial chemicals, urban pollutants and contamination by emerging pollutants like micro-plastics and pharmaceutical compounds are comparatively very sparsely studied globally. With proliferating anthropogenic pollution, periodic monitoring and maintaining a more comprehensive inventory of streambed pollutants is of paramount importance for managing the overall stream ecosystem health, especially in developing and underdeveloped countries where pollutants are discharged into the streams without effective pre-treatment.

\section{Types of Streambed Pollutants and Sources}

Sediments are integral part of a stream system and its occurrence could be attributed to the natural processes of erosion from upland watershed and scouring along the banks of the stream [81, 82, 83]. Although sediment transport is a natural process, the anthropogenic developments/activities along the river/stream network could highly increase the extent of sediments being discharged into the fluvial systems $[84,85]$. Streambeds receive a variety of pollutants that originate both from point and non-point sources. These pollutants could be broadly divided into three categories - a) physical, b) chemical and microbial or biological in nature and origin. In the subsequent paragraphs, we elaborate on each of these different 
pollutants types and their sources.

\subsection{Physical}

Fine sediments (size $\leq 2 \mathrm{~mm}$ diameter) are the most abundant source of streambed pollution [16, 17, 86]. Although streams are natural transporter of suspended sediments, increasing anthropogenic activities such as alteration of flow regime, deforestation and mining have drastically increased the input of fine sediments to the streams $[87,88]$. Depending on the size, texture, source and physico-chemical properties of the sediment particles, fine sediments have varying polluting potential on the streambed [89]. Plastic debris is the next major physical pollutant observed in streambeds [90]. The plastic pollutants emerge from a wide range of sources varying from household polyethylene bags to thermoplastic elastomers from discarded automobile parts. The fragmentation of macro-plastics (including bio-degradable polymers) in the aquatic environment leads to the formation of micro-plastics with modified polymer physico-chemical properties which further pollute the streambed ecosystems [91, 92]. Other physical pollutants include scrap materials such as e-waste, metals, and rubber products (e.g. tyres) [93].

\subsection{Chemical}

The most common chemical streambed pollutants are pesticides, polycyclic aromatic hydrocarbons (PAH) (oil based contaminants) and heavy metals $[26,94,95]$. Among the pesticides, organochlorine insecticides such as DDT, chlordane and dildrien are the most widely observed contaminants that are drained into the stream system, and these pollutants have the tendency to persist within the streambed sediments for years (legacy contaminants) $[96,97]$. Although the use of insecticides has been discontinued in most of the countries, they are still one of the major chemical pollutant found in the streambed sediments. Examples of insecticides include chloropyrifos, liadane and endosulfan; some herbicides such as benfluralin, bensulidine and diuron; and fungicides such as dichlone, tebuconazole and zineb [24, 98, 99]. The most commonly reported heavy metals in streambed sediments are $\mathrm{Pb}, \mathrm{Fe}, \mathrm{Zn}, \mathrm{Ni}, \mathrm{Cr}, \mathrm{Cu}$ and $\mathrm{Mn}$, and among these, $\mathrm{Ni}$ and $\mathrm{Zn}$ have a higher polluting potential at even smaller concentrations [78, 100, 101]. Among PAH contaminants, benzofluoranthene, fluoranthene and anthracene have more contamination potential and hence, could be classified as 'high risk" streambed pollutants [26]. Other than the pollutants mentioned above Polychlorinated biphenyl (PCB) and fire retardant chemicals have also been identified within streambeds [24]. A large proportion of the above-mentioned pollutants reaches the streams as a result of the discharge of partially treated or untreated industrial wastes, domestic sewerage and runoff from the agricultural farmlands $[34,102,103]$. Further in urban catchments, runoff from roads causes pollutants such as tar, dust and petroleum residues to enter into the streams

\footnotetext{
${ }^{1}$ high risk: These pollutants are probable carcinogens and are harmful to both aquatic life and humans even at smaller concentrations
}

leading to streambed pollution.

Apart from these classical pollutants, a new category of pollutants widely referred to as 'Emerging contaminants'are being discovered in water sources around the world which includes pharmaceutical wastes (such as antibiotics, hormones, anti-diabetic and anti-inflammatory drugs), personal care products and micro-plastics $[30,104,105]$. Although the toxicological impact of most of these emerging contaminants has not been known yet, many of these contaminants undergo bio-chemical degradation in the environment and form active compounds which have been identified to cause severe health problems in humans and also to the aquatic life [106, 107]. Some recent studies have also found the presence of a number of emerging contaminants persisting within streambed sediments [30, 108, 109]. Table 1 provides details of different types of chemical pollutants that enter into streambed including its sources and effects.

\subsection{Biological or Microbial}

Discharge of untreated or partially treated sewerage, untreated solid waste, agricultural and storm water runoff and disposal of municipal waste into the streams are the major sources of microbial pollution of streambeds $[110,111]$. Some of these pollutants include fecal matter, bacteria, nutrients and micro-organisms [112]. Studies indicate that the concentration of fecal bacteria can be as high as 1.2 to 58 times near the streambed surface than in the overlying water column $[113,114]$. Elevated supply of nutrients such as phosphorus and nitrogen is also a source of streambed pollution, since this leads to a rise in phytoplankton and aquatic plant population, which negatively impact on water quality and fish communities $[115,116]$. Further, algal bloom in streams creates a diel variation in the stream ecosystems which leads to the incubation and growth of heterotrophic bacteria within the streambed [117].

\section{Impacts of Streambed Pollution}

\subsection{Hydrological Impacts}

Fine sediments settle at the bottom of the streambed to affect the hydro-geological features of the streams including hyporheic exchanges, streamflow characteristics and biogeochemical properties of the streambed [118]. Deposition of fine sediments (most common and abundant physical pollutant) on/into the streambeds, referred to as fine sediment clogging, has been associated with the reduction in hydrological connectivity (infiltration or exfiltration processes) across the sediment-water interface $[119,120,121,122]$. Particularly, influence of fine sediment clogging on hyporheic flow regime has received a lot of attention in the past $[11,123,124,125$, $126,127]$. For instance, laboratory experiments conducted in re-circulating flumes have demonstrated that clogging of streambeds reduces the bed permeability (or closely associated hydraulic conductivity) resulting in the reduction of both hyporheic flux and exchange depth [11, 126]. Similarly, recent 
studies suggest that the residence times of water/solutes in streambeds could increase due to fine sediment clogging and subsequently claims that the pore spaces may get completely clogged with the increasing fine sediment input resulting in disconnection between surface and sub-surface waters [127]. The influence of fine sediment accumulation on hydrological exchanges across the sediment-water interface depends on factors such as groundwater inflow/outflow, stability of the streambeds, streambed composition, and chemical properties of fine sediments [11, 124, 127, 128].

Plastics (including micro-plastics and degraded plastic compounds) are another major class of streambed pollutants that are highly persistent $[20,129,130]$. The impacts of plastic pollution are generally spatially limited, however, its extent and severity is much drastic than fine sediments owing to the nature and toxicity of the materials [131, 132]. Plastics settle at the streambed surface and forms a blanket causing hydrological disconnections across the sediment-water interface [133]. The other class of physical pollutants such as scrap materials including rubber tyres and metals could also affect the quality of the stream water, however, their effect on the hydrology of the stream ecosystem is insignificant since they are present only in lower quantities $[134,135]$.

The accumulation intensity and propagation of streambed pollutants (mostly fine sediments) are directly linked to channel flow conditions. High flows within the stream channel (i.e., during floods) creates upward currents (turbulence) which results in suspension of the settled bed contaminants [136] and their transport to the nearby reservoir/ponds affect much larger key ecosystem components [137]. However, the transport and the extent of transport of the sediments/polluted sediments under such conditions depend highly on the degree of turbulence, physico-chemical properties of the sediment and the nature of transition (i.e., erosion or deposition event) $[138,139]$. During peak flows (floods), there exists a chance of huge quantity (volume) of the polluted streambed sediments being eroded and transported to water storage reservoirs thus polluting the water stored for drinking and irrigation activities. The deposition of fine sediments in reservoir systems (also referred to as silting) is a major threat to reservoirs, and with time a new bund/dam might be required on downstream side to serve the reservoir purpose, since desilting becomes economically and physically non-viable solution $[140,141]$. In urban areas although the relative contribution of different factors causing streambed pollution have not been known yet, the extent of urbanization, river network maintenance and contaminants from various point and non-point sources (e.g. PAH's and heavy metals) are known to affect the extent of streambed pollution [26, 142, 143]. On the other hand, the cascade of fine sediments in urban systems mostly end up in storm water systems and detention basins (causing serious maintenance burden), and the presence of coarse grained sediments (size $>0.5 \mathrm{~mm}$ ) in urban streams limits its geomorphic potential and ecological value [144].

In comparison to the fine sediment pollution, the chemical and biological streambeds pollutants may have a comparatively lesser hydrological impacts. Nonetheless, streambed pores may get clogged due to excessive microbial growth (referred to as bio-clogging) and precipitation of chemical compounds such as iron and manganese [145, 146]. For instance, presence of nutrients such as nitrates and phosphates in higher concentrations may result in increase in microbial biomass and the development of biofilms could reduce the permeability of bed sediments and subsequently impede the hydrological exchange across the sediment-water interface.

\subsection{Ecological Impacts}

A streambed hosts a wide range of floral and faunal species and its pollution will have direct implications on the biotic functioning of stream ecosystems. The effects of fine sediment accumulation on in-stream faunal organisms such as macroinvertebrates and fish has been subject to extensive research in the past [147, 148, 149, 150, 151, 152]. It is well-known that fine sediment accumulation on/into the streambeds reduces the bed porosity and permeability resulting in reduction of density and biodiversity of macroinvertebrates [121, $152,153,154]$. Increasing fine sediment accumulation has been demonstrated to limit the use of streambed sediments as refugium by the macroinvertebrates during adverse hydrological conditions such as dry seasons [153, 155]. Higher suspended sediment concentration has been reported to adversely affect the growth rates of fish and impair their respiratory system [156, 157]. Similarly, fine sediment infiltration may occur in the spawning regions of fish leading to egg mortalities due to limited supply of oxygen and other essential nutrients [158]. Besides the faunal organisms, excessive fine sediment concentrations in streams has deleterious impacts on in-stream vegetation such as macrophytes and diatoms $[118,159,160,161,162,163]$. High suspended sediments in the water column limits the light availability for the macrophytes present below the surface and hampers the photosynthesis activity and results in reduction of the growth rates of macrophytes [164]. Similarly, deposited fine sediments may not act as conducive substrate (compared to coarser bed particles) for the diatoms to adhere and grow leading to reduction in their biomass and richness.

Consumption of micro-plastics (size typically $<5 \mathrm{~mm}$ ) present in the streambed by aquatic organisms lead to fatal effects. The main routes of micro-plastic intake in aquatic organisms are through respiration and ingestion [165]. Its presence has been found in a numerous taxa of organisms at every tropic level including mussels and zooplanktons in their body organs such as lever, gut, stomach and respiratory tract [166, 167, 168]. Micro-plastics significantly impact smaller benthic organisms as identified in representative samples of Aulacomya atra, Helcogrammoides cunninghami, and Ribeiroclinus eigenmanni in urban streams of Patagonia, Argentina [169]. Through bio-accumulation in the food chain micro-plastics have the potential to move to organisms in the higher tropic levels of the aquatic and terrestrial food web and even reach humans 
to cause various problems including but not limited to cell damage, oxidative stress, metabolic change and immunologic responses [170]. Further degradation products of plastics and micro-plastics present in the streambed could transform into adverse polluting compounds and persist in the streambed for years to cause further pollution $[131,171]$.

The chemical pollution in streams, both due to presence of toxic chemicals in surface and pore waters and contaminants adsorbed on fine sediment surface, has deleterious influence on the stream ecology [172, 173, 174, 175, 176, 177]. For example, higher metal concentrations in streambeds have been reported to reduce the richness and density of faunal organisms leaving only tolerant species surviving in the contaminated habitats [175, 178, 179, 180]. Similarly, pesticide and sewage pollution of streams has been observed to alter the community structure of macroinvertebrates with reduction in biodiversity as the marked feature [181, 182, 183]. Toxic inorganic and organic substances associated with fine sediments have also been demonstrated to negatively influence the macroinvertebrates species in streams [59, 173, 182]. Further, heavy metals and hydrocarbons attached with the deposited sediments also affect other aquatic flora and fauna including fishes and vegetation [184, 185, 186]. Indeed, polluted streambeds prevent the growth of riparian vegetation and severely affect the buffer strip ecosystems [118, 187].

Another widespread ecological impact of the chemical contamination of streambeds is the accumulation of toxins into the bodies of in-stream flora and fauna, a process generally referred to as bioaccumulation [188, 189, 190, 191, 192, 193]. For example, previous research has shown that heavy metals such as lead and cadmium accumulate into the tissues of fish and macroinvertebrates which can subsequently hamper their growth and reproduction rates [189, 192]. In addition to this, turbid streamflow and ongoing sediment transport processes cause the pollutants to propagate along the stream and the migration of affected aquatic organisms (within the stream) enables the pollutant to get transported within the stream system [194]. Due to persistence, bio-magnification, bio-accumulation and migration of fish population, the point source streambed contaminants that are usually bound to an area, can influence the organisms at higher trophic levels and easily reach the aquatic ecosystems of other remote parts of the catchment which are pollution free or even reach the humans through food chain [195, 196, 197].

Presence of biological pollutants in the streambed could also create an ecological imbalance along the streambed [198, 199]. For instance, fecal material that reaches the stream via domestic sewage discharge is more active at the sedimentwater interface and can potentially increase the biological oxygen demand (oxygen required to bio-chemically degrade the organic matter in water) $[200,201]$. This may result in shortage of oxygen supply for the stream inhabitants and restrict their growth [202, 203]. The ecological impacts of these pollutants are much higher especially during the low flow seasons, since their concentration in the stream typically increases multi-fold [117, 204, 205]. Further, the abundance and activity of bacterial pollutants exhibit a functional layering effect near the hyporheic region, for example, vertical zonation of Particulate Organic Carbon content and variations in respiration rate is typically observed [205].

Though streambed pollution has an extensive impact on the stream ecosystems, their monitoring and assessment across the globe is limited, and even if such undertaking is performed, their findings are often limited since only certain type of biota is sampled or the span of monitoring is not adequate. Hence, in most cases the ecological impacts of streambed pollution assessed are subjective in some way or the other since no specific standards exist for quantifying the impacts. Framing standards and guidelines at both local and global levels are inevitable to quantify and assess the impacts of streambed pollution on stream ecosystems.

\subsection{Geomorphological Impacts}

Fine sediments are episodically eroded and deposited in the stream environment. As a consequence, fine sediments could potentially modify the structure, composition, and morphology of streambeds [123, 206, 207]. For instance, the aggradation and degradation of sediments modifies the streambed morphology (e.g. height of dunes or dimensions of pool-riffle sections) and alter the fluvial geomorphology and floodplain landforms [208]. Similarly, the accumulation of sediments on/into the streambeds increases the proportion of finer material in the bed resulting in instability of beds. Further, building of sediments along the stream could decrease the depth of water column across the stream channel and could potentially increase the stream velocity and erosive power of flowing water leading to scouring of bed/banks along the river and deepening of the downstream riverbed [209]. This with time could lead to the meandering of the stream and change the geometry of the stream channel. The other geological impacts associated with streambed pollution includes the persistent variations in streambed substrate/sediment properties, alteration of pore-scale processes and stratigraphy of floodplains [210]. For instance, Chen et al., (2008) [211] documented that fluid flow (stream water) and particle transport (fine sediment transport) can cause heterogeneities at the surface of the media (streambed surface) and subsequently affect the hydro-geological properties (e.g., permeability) of the media (streambed). In addition to this, streambed pollution could also prevent the natural weathering of rocks, since the fine sediment and pollutant blanket separate the underlying rock layer from moving water [212]. As the accumulation of fine sediments reaches a limit, allowing the stream to morphologically stabilize, as they have done through time in the past, is the most practical/feasible solution to mitigate the effects of streambed pollution by fine sediments. In instances where it is not possible, dredging of the river bed is necessary to preserve the hydro-geomorphological features of the streambed. However, scooping out polluted sediments with a dredge from the streambed is a costlier measure and its disposal would be 
another pressing environmental issue in many regions.

\subsection{Biochemical Impacts}

Prolonged exposure of streambed sediments to the contaminants could eventually alter the chemical properties of the sediments [213]. For instance, in Oak Ridge, USA, after the historical industrial releases of mercury $(\mathrm{Hg})$ in the East Fork Poplar Creek, a study has found evidences of geochemical transformation of sediments into Hg-bound sediments and degradation of in-stream environment [214]. In Rio San Giorgio, a streambed with dense vegetation and affected by mine pollution was studied by De Giudici et al., (2017) [215]. Their findings suggest that microbial precipitation of metals leads to the formation of less toxic precipitates, thus reducing the risk of chemical contamination. However, these metal precipitates may potentially clog the streambed pores, which in turn, could modify the exchange of mass and energy across the sediment-water interface $[216,217]$. Streambed pollution may also strongly affect the biogeochemistry within the hyporheic zones and subsequently modify the flux of several nutrients (including nitrogen and oxygen) across the sedimentwater interface $[218,219,220]$. In some instances, the streambed pollutants react with the anoxic groundwater discharges near the streambed surface (also referred to as redox hot spots) to form several oxide precipitates which influence the release of metal ions and other nutrients to the flowing water [221]. Indeed, a recent study indicates that microbial metabolic activity near the streambed surface synthesize organic pollutants such as the allochthonous carbon from agricultural sites to produce greenhouse gases (e.g., methane and carbon di-oxide) [222].

Streambed pollution has a wide range of impacts on the catchment hydrology. Some studies report that the streambeds act as refining barriers to prevent groundwater pollution, however, as the pollutants settle along the streambed it gains potential to leach into groundwater on account of prolonged percolation, more effectively in Karst aquifers [10]. The colmated riverbed zones and their vertical extent along the stream course are characterized by anoxic and anaerobic conditions caused by demobilized pollutants [223, 224]. In urban areas, precipitation runoff to the dry streambeds causes degradation and inter-mixing of pollutants with the eroded stream substrate leading to decreased dissolved oxygen content and water quality issues in the stream [102]. Streambed pollution although adversely affect the quality of water, aquatic biota, and wildlife that are directly dependent on the stream water, its impacts are mostly non-lethal on other associated ecosystems $[225,226]$. In addition to aforementioned effects, the foam and froth nuisance near urban streams created by the suspended pollutants, including organic and soluble chemicals from domestic sewage and industrial plants, lead to eutrophication effects and reduced oxygen levels in surface waters [227].

The new evolving category of emerging contaminants (tabulated in Table 1) within streambeds induce toxicity, reduce dissolved oxygen content, and hinders photosynthesis posing serious threat to the existence of microbiota and dependent aquatic ecosystems [29, 106]. Richmond et al. (2017) [228] documents literature examples to demonstrate the serious eco-biological consequences of pharmaceutical contaminants even at low or miniscule concentrations. Severe to subtle exposure of benthic ecosystems to streambed contaminants paradoxically alter the visual behaviours, processes, resilience and community structure of benthic systems [229, 230].

\section{Impact Assessment Methodologies: Pros and Cons}

Quantifying different streambed pollutants and their impacts on stream ecosystem functioning has been a difficult task (Figure 1 summarizes the eco-hydro-geo-chemical impacts of streambed pollution). In the literature, the impact assessment of streambed pollution has been primarily focused on understanding their ecological effects [26, 52]. Unlike the physical transport process (e.g., suspended pollutants transported by stream water), quantification of pollutant transport through bioaccumulation in riverine species is highly impractical due to variations in the nature, range and toxicity of the pollutant being transported [231, 232, 233]. This subsequently makes it difficult to detect, quantify or pin-point a specific pollutant at a given contamination site. Challenge is therefore to accurately assess the impacts of the pollutants as well as the remediation measures undertaken $[234,235]$. The use of sediment cores for sample collection has been commonly practiced to analyze the streambed pollution $[43,47,236]$. The popularity of the sediment core method can be attributed to its effectiveness in reconstructing historic water quality in the stream and in detecting the presence of legacy contaminants $[47,237]$. Several indices such as Enrichment factor, Pollution Load Index, Sediment Pollution Index, and Ceo-accumulation index are being used to quantify streambed pollution caused by heavy metals (Table 2 provides the limiting values of sediment pollution) [34, 238, 239, 240, 241, 242].

Source receptor modeling and mass fraction analysis are being widely used to identify potential organic pollutant sources such as PAH in streambed sediment samples [243]. Biofilms and aquatic organisms have been employed as bio-indicators to detect and assess the impacts associated with streambed pollution [244, 245]. The general impact assessment methodology includes finding the sources and occurrence of the pollutants, verification/quantification of the pollutant concentration in the streambed using analytical methods in the laboratory and comparing with standard values (as given in any guidelines) followed by statistical analysis and development of impact indices [44]. Statistical analysis such as 'partial canonical correspondence analysis' (pCCA) [246], correlation simulations, clustering (e.g. hierarchical clustering) and one-way analysis of variance are performed to determine the relative importance of different pollutants [247, 248]. Alternatively, monitoring of the microbial quantity in the streambed sedi- 


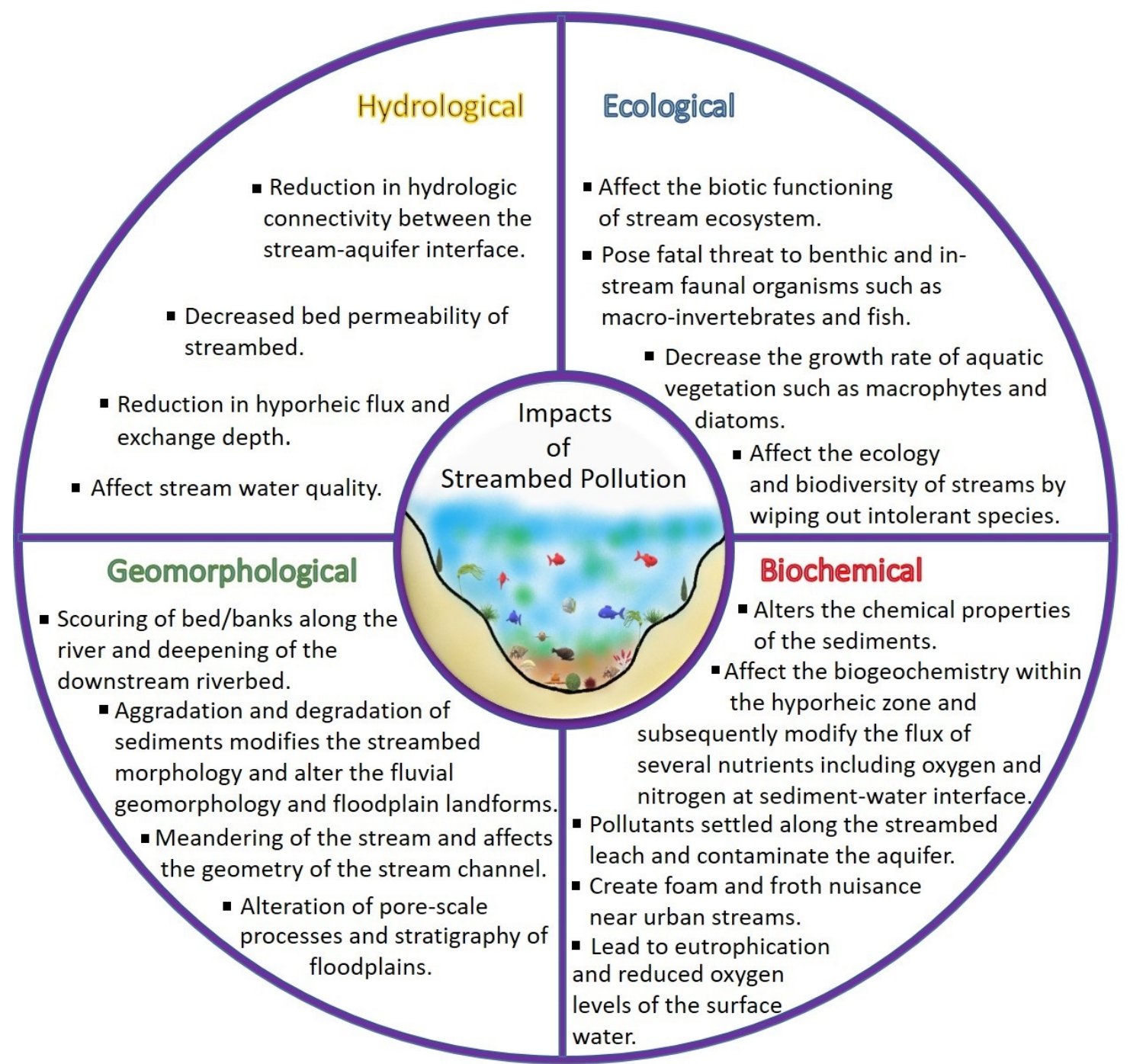

Figure 1. Summary of the Ecological, Hydrological, Geomorphological and Biochemical (Eco-hydro-geo-chemical) impacts of streambed pollution

ments generally aid to analyze the samples for various bacterial indicators and a sharp decline in the microbial colonies provide evidence for contamination of streambed [26]. Ecological impacts of streambed pollution can be assessed by ecosystem service loss as the function of potentially affected fraction (PAF) of species at different tropic level specifically during multi-substance contamination [249, 250]. Although a variety of methods exist to assess the ecological impacts of streambed pollution (e.g., spatial clustering or quantifying PAF), each of them differ either by the sample collection technique, site selection process or the species of biota sampled $[36,49,50,250,251]$. There is a need to develop comprehensive and standardized in-situ methods to investigate/analyze streambed pollution impacts. Lack of any approved monitoring/assessment methodology suitable for assessing the impacts of a whole range of pollutants (each contaminant are to be tested separately), makes the monitoring of streambed pollutants a labour intense and costly process.
With the current developments in the remote sensing technology, new approaches need to be developed to map vulnerable regions based on the severity and the extent of streambed pollution. Modeling frameworks need to be developed to clearly understand and substantiate the overall impacts of streambed pollution on the hydro-geological features of the stream and other associated natural systems (e.g., ponds and lakes). Though monitoring pollutants from diffuse sources is difficult, methods/techniques needs to be developed to monitor the entry and existence of harmful contaminants and pollutants of emerging concern within the streambeds. High quality standards need to be implemented for the treatment of domestic and industrial sewage, before wastewater is discharged into the streams. Necessary policy measures need to be worked out to prevent the entry of such toxic compounds into the streambeds. Additionally, development of frugal sensor based devices for monitoring of streambed pollution would be beneficial for in-situ monitoring. 
Lastly, the impacts of streambed pollution in different geographic regions needs to be studied in different contexts because the extent, severity and the nature of pollution vary largely from one stream to the other. To put this in perspective, streambed pollution in a properly managed stream in a developed country might constitute the presence of some emerging chemical pollutant in the streambed (and have lower impacts) while in some other region of the world it could mean the presence of extensive range of chemicals (from untreated domestic and industrial discharge), plastics and fine sediments which could have severe impact on the stream ecosystem health.

\section{Mitigation and Remediation Strategies}

While the success of remediation of streambeds is very scarcely documented in the literature, several physical, chemical, and biotechnological remediation techniques (Figure 2) show great promise in attenuating the negative effects of polluted sediment loads [252, 253]. Cost-effective and technically feasible in-situ and ex-situ remediation techniques are available for successful contaminated sediment management [254]. The impacts of streambed pollution will gradually reduce when conservation management systems are planned and introduced at watershed scale. The most realistic solution to reduce the streambed pollution would be to ensure that the discharged effluents (both industrial and domestic) are properly treated before they are discharged into streams [255]. With regard to urban and industrial areas, appropriate policy measures for management of generated solid wastes and efficient storm water drains could prevent several non-degradable contaminants entering the natural streams or at least reduce the extent of the streambed pollution [256].

\subsection{Physical Measures}

Based on the physical characteristics of the pollutants and site specific environment, physical remediation techniques such as mechanical separation, solidification/stabilization, monitored natural recovery, isolation and containment methods have been employed to manage and transform the pollutants into less toxic forms $[257,258]$. Considering the subsurface heterogeneity, physical methods cannot guarantee or assure the uniformity of remediation and usually take longer treatment time [252]. Dredging is the most commonly practiced mechanical technique used to placate the impacts of extensive streambed pollution by fine sediments [254, 259]. It is to be noted that some countries have even managed to convert/process the contaminated dredged sediments into marketable products (a sustainable option) after suitable treatment, which is indeed quite costly [57]. Dredge materials are sometimes stabilized by pump-and-treat systems [260]. Pumpand-treat system, also referred to as hydraulic dredging, is generally employed where the removal of the contaminants that

\footnotetext{
${ }^{2}$ Structural controls - Dykes, Barriers, Sediment Traps, Silt Fences and Sediment Basin
}

persist in the sub-surface is not plausible through bio-chemical methods [260, 261]. The dredged sediments in the form of slurry is transported through pipelines to a repository area and are treated ex-situ [262]. Multi-purpose detention or retention ponds prove effective in reducing the pollutant load (such as metals, solid debris, nutrients, and chemical and biochemical oxygen demand) of urban streamflow $[263,264]$. Structural controls include construction of dykes or barriers, vegetated riparian buffers, silt fences, sediment traps, or spreading of filter fabrics (such as hay bales) in drainage runoff zones are proven to reduce the incidence of both erosion and pollution loads [265].

\subsection{Chemical and Biotechnological Measures}

Chemical treatment methods such as oxidation-reduction processes, immobilization techniques, and dechlorination methods are highly specific for certain pollutants [266]. Usually, the stream invertebrates, consortia of microorganisms and aquatic flora are involved in the bioremediation process to degrade the streambed pollutants bio-chemically by implementing in-situ or photo-bioreactor approaches [112]. Bioleaching, bio-venting, phyto-remediation, phyto-extraction, phyto-stabilization, bio-sorption, phyto-volatilization, rhizofilteration, phyto-degradation are few other biological treatment methods that transform or degrade streambed contaminants into non-toxic form [142, 266, 267]. The drawbacks of chemical and biological techniques include uncertain reaction rates, factors that suppress microbial activity, problems in delivery of necessary oxidant/ bacteria or fungi/solvent materials to polluted zones, yield of an inert end-product and uncertainties in application of new technology [268]. In general, physical remediation measures are not so expensive compared to chemical and biotechnological measures and, therefore, might be more suitable where quick remediation is required.

Several factors including the length of the stream over which the restoration is undertaken, presence of any constraints (e.g. downstream barriers), nature of contamination, water quality, geology, presence of biological communities for recolonization and the topography of the remediation site within the catchment area affect the success of the mitigation efforts [269, 270]. Well-designed streambed remediation program should include a component of constant monitoring of the biological and physico-chemical settings so that the success of restoration can be documented, studied and improved [269]. However, stream monitoring post-restoration is often overlooked because of funding limitations. Carefully planned and executed streambed restoration programs by the U.S. Geological Survey in the Mineral Creek and High Ore Creek valley in Colorado and Montana of USA, respectively, illustrates how a successful streambed remediation program functions where significant ecological recovery is achieved [271, 272].

While several methods exist for mitigating or remediating or managing streambed pollution, they are often costly, and many countries across the world do not have adequate resources to adopt them. If only a certain stretch of streambed 


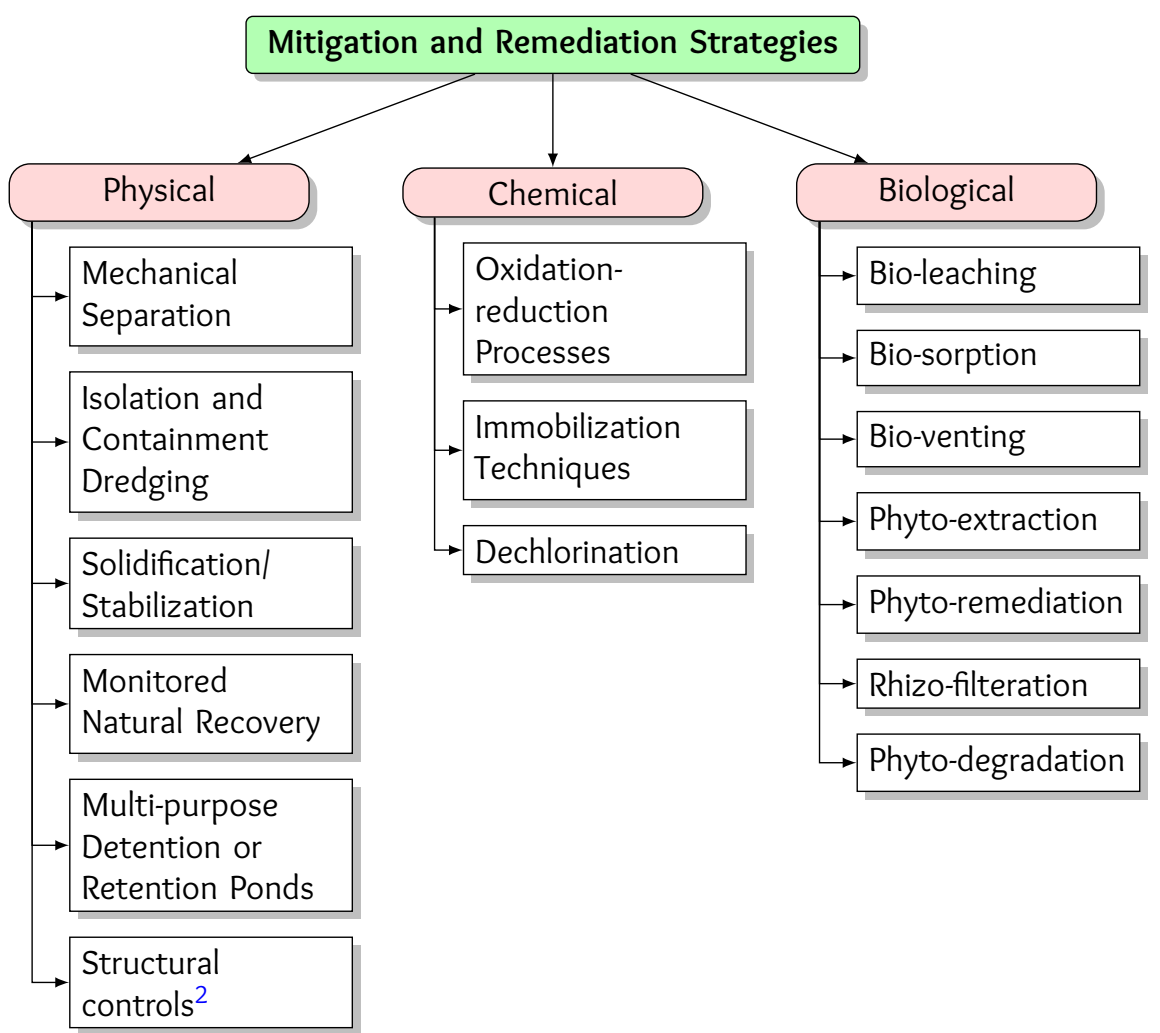

Figure 2. Mitigation and remediation strategies used for managing streambed pollution

is polluted with multiple pollutants, (such as, fine sediments, pesticides, micro-plastics and heavy metals) the ecological damage to the stream system in such stretches becomes irreversible as the remediation becomes too costly or infeasible. If such extensive stream pollution is observed, particularly in under-developed and developing countries, the only option for the people is to switch to alternate sources for drinking water consumption and other critical socio-economic activities. The most economical solution to control/prevent streambed pollution anywhere, would be to treat the effluents and wastes before discharging them into the stream system. However, the development or creation of infrastructure for such treatment facilities is very costly and in some cases treatment solution does not exist (e.g., emerging contaminants such as pharmaceutical degradation products), therefore the pollution monitoring/control agencies overlook these illegal discharges until public outcry or extensive pollution crisis occur abruptly. Hence, novel state-of-the-art sustainable treatment technologies need to be developed to montitor and prevent the discharge of pollutants and harmful effluents into the stream systems.

\section{Conclusions}

Streambed pollution is a global environmental issue that seriously threatens the natural eco-hydrological processes and geochemical facies of the stream ecosystem. In addition to fine sediment pollution, the occurrence and distribu- tion of sediment-associated persistent and legacy contaminants within streambeds portray the substantial potential of streambeds to act as a reservoir of such contaminants, and with the increasing anthropogenic pollution caused by spurring population, the magnitude of streambed pollution is expected to increase tremendously in the near future. Global inventory of streambed pollution studies suggests that there are gaps in the current understanding of the multi-faceted impacts of streambed pollution, and most of countries do not have a proper infrastructure to monitor and assess the hazardous impacts of streambed pollution, let alone the planning and implementation of the mitigating strategies. While the impacts of fine sediment pollution have been adequately studied, the sub-lethal effects of other pollutant sources on the fluvial habitats need to be studied further to identify any critical thresholds of ecological damage. It is unlikely that best management practices have really focused sufficiently to consider and address the complexity of the streambed pollution. Furthermore, since floodplains act as semi-permanent sinks for the accretion of anthropogenic sediments (enriched by debris), the functions and buffer capacity of the floodplains have progressively diminished over time. Expanding from the local pollution data to general interpretations is a challenge, as information is often insufficient, necessitating assumptions that are not easily validated. Hence, continuous updates and review of impact assessment methodologies are critical to better understand and model the fate and transport of streambed pollutants. Further research on innovative strategies to moni- 
tor and manage the pollutants entering the stream network is crucial to control and mitigate the extent and severity of streambed pollution, especially in the vulnerable regions. Hitech, state-of-the-art monitoring stations within the river network may reveal the circumstances of substantial pollution in streams on real-time basis and assist researchers to identify patterns and spatial deposition trends in contaminant deposition.

\section{References}

[1] D.J. McCabe. Rivers and streams: Life in flowing water. Nature Education Knowledge, 3(10):19, 2011.

[2] E. Wohl. The significance of small streams. Frontiers of Earth Science, 11(3):447-456, 2017.

[3] Scott G Leibowitz, Parker J Wigington Jr, Kate A Schofield, Laurie C Alexander, Melanie K Vanderhoof, and Heather E Golden. JAWRA Journal of the American Water Resources Association, 54(2):298-322, 2018.

[4] Ritu Singh Rajput, Sonali Pandey, and Seema Bhadauria. Status of water pollution in relation to industrialization in Rajasthan. Reviews on Environmental Health, 32(3):245-252, 2017.

[5] Philippe Namour, Laurent Schmitt, David Eschbach, Bertrand Moulin, Guillaume Fantino, Claire Bordes, and Pascal Breil. Stream pollution concentration in riffle geomorphic units (Yzeron basin, France). Science of the Total Environment, 532:80-90, 2015.

[6] Pedro Alexandre Sodrzeieski, Leonardo Capeleto de Andrade, Tales Tiecher, and Flávio Anastácio de Oliveira Camargo. Physico-chemical variability and heavy metal pollution of surface sediment in a non-channeled section of Dilúvio Stream (Southern Brazil) and the influence of channeled section in sediment pollution. Revista Ambiente É Água, 14(1):e2285, 2018.

[7] C J Velz. Applied Stream Sanitation. John Wiley, United States, second edition, 1984.

[8] Svenja Boehler, Ruben Strecker, Patrick Heinrich, Erik Prochazka, Grant L Northcott, James M Ataria, Frederic DL Leusch, Thomas Braunbeck, and Louis A Tremblay. Assessment of urban stream sediment pollutants entering estuaries using chemical analysis and multiple bioassays to characterise biological activities. Science of the Total Environment, 593:498-507, 2017.

[9] Sarah Francesca Lynn Lynch. Establishing the environmental risk of metal contaminated river bank sediments. PhD thesis, School of Geography, Earth and Environmental Sciences, University of Birmingham, 2015.
[10] P.L. Younger, R. Mackay, and B.J. Connorton. Streambed sediment as a barrier to groundwater pollution: insights from fieldwork and modelling in the River Thames Basin. Water and Environment Journal, 7(6):577-585, 1993.

[11] Kristin J Rehg, Aaron I Packman, and Jianhong Ren. Effects of suspended sediment characteristics and bed sediment transport on streambed clogging. Hydrological Processes: An International Journal, 19(2):413-427, 2005.

[12] Eleonore Resongles, Corinne Casiot, Remi Freydier, Laurent Dezileau, Jerome Viers, and Francoise ElbazPoulichet. Persisting impact of historical mining activity to metal $(\mathrm{Pb}, \mathrm{Zn}, \mathrm{Cd}, \mathrm{Tl}, \mathrm{Hg})$ and metalloid $(\mathrm{As}, \mathrm{Sb})$ enrichment in sediments of the Gardon River, Southern France. Science of the Total Environment, 481:509-521.

[13] Edwin D. Ongley. Control of water pollution from agriculture, volume FAO Irrigation and Drainage paper 55. Food and Agriculture Organization of the United Nations, Rome, 1996.

[14] IN McCave, Barbara Manighetti, and SC Robinson. Sortable silt and fine sediment size/composition slicing: parameters for palaeocurrent speed and palaeoceanography. Paleoceanography, 10(3):593-610, 1995.

[15] E Evans and AC Wilcox. Fine sediment infiltration dynamics in a gravel-bed river following a sediment pulse. River Research and Applications, 30(3):372-384, 2014.

[16] Christoph Hauer, Patrick Leitner, Günther Unfer, Ulrich Pulg, Helmut Habersack, and Wolfram Graf. The role of sediment and sediment dynamics in the aquatic environment. In S Schmutz and J Sendzimir, editors, Riverine Ecosystem Management, Aquatic Ecology Series, volume 8, pages 151-169. Springer, Cham, 2018.

[17] Patrick Belmont, Karen B Gran, Shawn P Schottler, Peter R Wilcock, Stephanie S Day, Carrie Jennings, J Wesley Lauer, Enrica Viparelli, Jane K Willenbring, Daniel R Engstrom, et al. Large shift in source of fine sediment in the upper mississippi river. Environmental Science $\mathcal{E}$ Technology, 45(20):8804-8810, 2011.

[18] María Jesús Belzunce, Oihana Solaun, José Antonio González Oreja, Esmeralda Millán, and Víctor Pérez. Contaminants in sediments. In Á. Borja and M. Collins, editors, Oceanography and Marine Environment of the Basque Country, volume 70 of Elsevier Oceanography Series, chapter 12, pages 283-315. Elsevier, 2004.

[19] Eva-Maria Lummer, Karl Auerswald, and Juergen Ceist. Fine sediment as environmental stressor affecting freshwater mussel behavior and ecosystem services. Science of the Total Environment, 571:1340-1348, 2016. 
[20] A.M.D Brasher, Reuben H Wolff, and Corene D Luton. Associations among land use, habitat characteristics, and invertebrate community structure in nine streams on the Island of Oahu, Hawaii, 1999-2001. Water resources investigations report 03-4256, US Geological Survey, Reston, Virginia, 2004.

[21] Hyun-Min Hwang, Peter G Green, and Robert W Holmes. Anthropogenic impacts on the quality of streambed sediments in the lower Sacramento River watershed, California. Journal of Environmental Science and Health, Part A, 44(1):1-11, 2009.

[22] Thomas J Lopes and Edward T Furlong. Occurrence and potential adverse effects of semivolatile organic compounds in streambed sediment, United States, 1992-1995. Environmental Toxicology and Chemistry: An International Journal, 20(4):727-737, 2001.

[23] A.M.D. Brasher and Reuben H Wolff. Relations between land use and organochlorine pesticides, PCBs, and semivolatile organic compounds in streambed sediment and fish on the Island of Oahu, Hawaii. Archives of Environmental Contamination and Toxicology, 46(3):385-398, 2004.

[24] Lisa H Nowell and Peter D Capel. Pesticides in stream sediment and aquatic biota: Distribution, trends, and governing factors. CRC Press, Boca Raton, FL, 1999.

[25] Austin K Baldwin, Steven R Corsi, Samantha K Oliver, Peter L Lenaker, Michelle A Nott, Marc A Mills, Gary A Norris, and Pentti Paatero. Primary sources of polycyclic aromatic hydrocarbons to streambed sediment in great lakes tributaries using multiple lines of evidence. Environmental Toxicology and Chemistry, 39(7):1392-1408, 2020.

[26] Gary Beasley and Pauline E. Kneale. Assessment of heavy metal and PAH contamination of urban streambed sediments on macroinvertebrates. In R.K. Wieder, M. Novák, and M.A. Vile, editors, Biogeochemical Investigations of Terrestrial, Freshwater, and Wetland Ecosystems across the Clobe, page 563-578. Springer, Dordrecht, 2004.

[27] P.M. Randall and S. Chattopadhyay. Mercury contaminated sediment sites-An evaluation of remedial options. Environmental Research, 125:131-149, 2013.

[28] Keith A Loftin, M.T. Meyer, and D.W. Kolpin. Assessment of antibiotic residues in extracted biosolids, manure, soils, and streambed sediment in the United States: A source reconnaissance. In 6 th International Conference on Pharmaceuticals and Endocrine Disrupting Chemicals in Water. National Ground Water Association, 2007.

[29] I. Peralta-Maraver, M. Posselt, D.M. Perkins, and A.L. Robertson. Mapping micro-pollutants and their impacts on the size structure of streambed communities. Water, 11(12):2610, 2019.
[30] E. Nilsen, E.T. Furlong, and R. Rosenbauer. Reconnaissance of pharmaceuticals and wastewater indicators in streambed sediments of the Lower Columbia River Basin, Oregon and Washington. JAWRA Journal of the American Water Resources Association, 50(2):291-301, 2014.

[31] R. Buckley, E. Clough, W. Warnken, and C. Wild. Coliform bacteria in streambed sediments in a subtropical rainforest conservation reserve. Water Research, 32(6):1852-1856, 1998.

[32] C. Mendoza-Lera, A. Frossard, M. Knie, L.L. Federlein, M.O. Gessner, and M. Mutz. Importance of advective mass transfer and sediment surface area for streambed microbial communities. Freshwater biology, 62(1):133-145, 2017.

[33] S.A. Bryce, G.A. Lomnicky, and P.R. Kaufmann. Protecting sediment-sensitive aquatic species in mountain streams through the application of biologically based streambed sediment criteria. Journal of the North American Benthological Society, 29(2):657-672, 2010.

[34] N. Dahri, A. Atoui, M. Ellouze, and H. Abida. Assessment of streambed sediment contamination by heavy metals: The case of the Gabes Catchment, South-eastern Tunisia. Journal of African Earth Sciences, 140:29-41, 2018.

[35] Martin Søndergaard and Erik Jeppesen. Anthropogenic impacts on lake and stream ecosystems, and approaches to restoration. Journal of Applied Ecology, 44(6):10891094, 2007.

[36] J.R. Deacon and N.E. Driver. Distribution of trace elements in streambed sediment associated with mining activities in the upper Colorado River Basin. Archives of Environmental Contamination and Toxicology, 37(1):7-18, 1999.

[37] Bruce L Rhoads and Richard A Cahill. Geomorphological assessment of sediment contamination in an urban stream system. Applied Geochemistry, 14(4):459-483, 1999.

[38] Marc S Greenberg, C Allen Burton Jr, and Carolyn D Rowland. Optimizing interpretation of in situ effects of riverine pollutants: Impact of upwelling and downwelling. Environmental Toxicology and Chemistry: An International Journal, 21(2):289-297, 2002.

[39] R. Miskewitz and C. Uchrin. In-stream dissolved oxygen impacts and sediment oxygen demand resulting from combined sewer overflow discharges. Journal of Environmental Engineering, 139(10):1307-1313, 2013.

[40] S.J. Washburn, J.D. Blum, J.D. Demers, A.Y. Kurz, and R.C. Landis. Isotopic characterization of mercury downstream of historic industrial contamination in the South River, Virginia. Environmental Science E Technology, 51(19):10965-10973, 2017. 
[41] A.S. Ward, J.A. Morgan, J.R. White, and T.V. Royer. Streambed restoration to remove fine sediment alters reach-scale transient storage in a low-gradient fifth-order river. Hydrological Processes, 32(12):1786-1800, 2018.

[42] C.J. Sprague and J.E. Sprague. Sediment pollution. GeoStrata Magazine Archive, 25(2):64-70, 2021.

[43] P.C. Van Metre, J.T. Wilson, G.R. Harwell, M.O. Gary, F.T. Heitmuller, and B. Mahler. Occurrence, trends, and sources in particle-associated contaminants in selected streams and lakes in Fort Worth, Texas. Tech. rep.,, U.S. Geological Survey, Austin, TX, 2003.

[44] J.T. Wilson. Assessment of selected contaminants in streambed-and suspended-sediment samples collected in Bexar County. Scientific investigations report 20115097, U.S. Geological Survey, Reston, VA, 2011.

[45] C. Konrad and A. Gellis. Factors influencing fine sediment on stream beds in the midwestern United States. Journal of Environmental Quality, 47(5):1214-1222, 2018.

[46] P.C. Van Metre and A.J. Horowitz. An 80-year record of sediment quality in the lower Mississippi River. Hydrological Processes, 27(17):2438-2448, 2013.

[47] P.C. Van Metre and E. Callender. Water-quality trends in white rock creek basin from 1912-1994 identified using sediment cores from white rock lake reservoir, Dallas, Texas. Journal of Paleolimnology, 17(2):239-239, 1997.

[48] P.C. Van Metre, E. Callender, and C.C. Fuller. Historical trends in organochlorine compounds in river basins identified using sediment cores from reservoirs. Environmental Science E Technology, 31(8):2339-2344, 1997.

[49] B. Mahler. Quality of sediment discharging from the Barton Springs system. USCS Fact Sheet 089-03, US Geological Survey, Austin, Texas, 2003.

[50] M.D. Munn and S.J. Gruber. The relationship between land use and organochlorine compounds in streambed sediment and fish in the Central Columbia Plateau, Washington and Idaho, USA. Environmental Toxicology and Chemistry: An International Journal, 16(9):1877-1887, 1997.

[51] E.N. Buttermore, W.G. Cope, T.J. Kwak, P.B. Cooney, D. Shea, and P.R. Lazaro. Contaminants in tropical island streams and their biota. Environmental Research, 161:615-623, 2018.

[52] US. EPA. Incidence and Severity of Sediment Contamination in Surface Waters of the United States. National Sediment Quality Survey. US EPA Office of Science and Technology, Washington DC, first edition, 1997.

[53] C. Kallis and D. Butler. The EU water framework directive: Measures and implications. Water Policy, 3(2):125-142, 2001.
[54] Jos Brils. SedNet corner (demand-driven, European sediment research network. Journal of Soils and Sediments, $4(2): 72-73$.

[55] Helge Bergmann and Vera Maass. Sediment regulations and monitoring programmes in Europe. In Susanne Heise, editor, Sediment Risk Management and Communication, volume 3 of Sustainable Management of Sediment Resources, pages 207-231. Elsevier, 2007.

[56] ALLES SpA. Green site : Supercritical fluid technologies for river and sea dredge sediment remediation. https: / / ec.europa.eu/environment/ life/project/, 2013. Accessed on: 5 October 2020.

[57] SEDI.PORT.SIL. Sediment management guidelines: Recovery of dredged SEDIments of the PORT of Ravenna and SILicon extraction. European Commission (ENV.E4 - LIFE Environment and Eco-innovation), Brussels, 2009. https: / / webgate.ec.europa.eu/life/ publicWebsite/index. cfm?fuseaction= search.dspPage\&n_proj_id=3682.

[58] B. Kronvang, A. Laubel, S.E. Larsen, and N. Friberg. Pesticides and heavy metals in Danish streambed sediment. Hydrobiologia, 494(1):93-101, 2003.

[59] P.W. Moran, N.E. Kemble, I.R. Waite, B.J. Mahler, L.H. Nowell, and P.C. Van Metre. Legacy and Current-Use Contaminants in Sediments Alter Macroinvertebrate Communities in Southeastern US Streams. Environmental Toxicology and Chemistry, 39(6):1219-1232, 2020.

[60] Marcos LS Oliveira, Binoy K Saikia, Katia da Boit, Diana Pinto, Bernardo F Tutikian, and Luis FO Silva. River dynamics and nanopaticles formation: a comprehensive study on the nanoparticle geochemistry of suspended sediments in the magdalena river, caribbean industrial area. Journal of Cleaner Production, 213:819-824, 2019.

[61] Isabel Ribeiro da Costa, Rita Fonseca, Catarina Pinho, Alexandre Araújo, Luísa Catarina Martins, Nuno Dias, Ana Isabel Janeiro, and Guilherme Freitas. Contaminated soils and sediments associated with zn ore metallurgy near the são francisco river, minas gerais (brazil). Environmental Earth Sciences, 77(5):1-23, 2018.

[62] Valdilene da Penha Rhodes, Jorge Carvalho de Lena, Camila Vidal Alves Santolin, Thais da Silva Pinto, Louise Aparecida Mendes, and Cláudia Carvalhinho Windmöller. Speciation and quantification of hg in sediments contaminated by artisanal gold mining in the gualaxo do norte river, minas gerais, se, brazil. Environmental Monitoring and Assessment, 190(1):49, 2018. 
[63] Jèssica Subirats, Xisca Timoner, Alexandre SànchezMelsió, José Luis Balcázar, Vicenç Acuña, Sergi Sabater, and Carles M Borrego. Emerging contaminants and nutrients synergistically affect the spread of class 1 integronintegrase (intil) and sull genes within stable streambed bacterial communities. Water Research, 138:77-85, 2018.

[64] Israel Razo, Leticia Carrizales, Javier Castro, Fernando Díaz-Barriga, and Marcos Monroy. Arsenic and heavy metal pollution of soil, water and sediments in a semiarid climate mining area in mexico. Water, Air, and Soil Pollution, 152(1):129-152, 2004.

[65] Damian B Gore, Nicholas J Preston, and Kirstie A Fryirs. Post-rehabilitation environmental hazard of $\mathrm{cu}, \mathrm{zn}$, as and $\mathrm{pb}$ at the derelict conrad mine, eastern australia. Environmental Pollution, 148(2):491-500, 2007.

[66] lan A Wright, Kasjan Paciuszkiewicz, and Nakia Belmer. Increased water pollution after closure of Australia's longest operating underground coal mine: a 13-month study of mine drainage, water chemistry and river ecology. Water, Air, E Soil Pollution, 229(3):1-20, 2018.

[67] X. Huang, J. Hu, C. Li, J. Deng, J. Long, and F. Qin. Heavy-metal pollution and potential ecological risk assessment of sediments from Baihua Lake, Guizhou, PR China. International Journal of Environmental Health Research, 19(6):405-419, 2009.

[68] W. Tang, B. Shan, H. Zhang, and Z. Mao. Heavy metal sources and associated risk in response to agricultural intensification in the estuarine sediments of Chaohu Lake Valley, East China. Journal of Hazardous Materials, 176(1-3):945-951, 2010.

[69] J. Song, X. Yang, J. Zhang, Y. Long, Y. Zhang, and T. Zhang. Assessing the variability of heavy metal concentrations in liquid-solid two-phase and related environmental risks in the Weihe river of Shaanxi province, China. International Journal of Environmental Research and Public Health, 12(7):8243-8262, 2015.

[70] Xiaodong Qu, Ze Ren, Min Zhang, Xiaobo Liu, and Wenqi Peng. Sediment heavy metals and benthic diversities in Hun-Tai River, northeast of China. Environmental Science E Pollution Research, 24(11):10662-10673, 2017.

[71] C. Ye, S. Li, Y. Zhang, and Q. Zhang. Assessing soil heavy metal pollution in the water-level-fluctuation zone of the Three Gorges Reservoir, China. Journal of Hazardous Materials, 191(1-3):366-372, 2011.

[72] Y. Xu, Q. Sun, L. Yi, X. Yin, A. Wang, Y. Li, and J. Chen. The source of natural and anthropogenic heavy metals in the sediments of the Minjiang River Estuary (SE China): Implications for historical pollution. Science of the Total Environment, 493:729-736, 2014.
[73] L. Han, B. Gao, H. Zhou, D. Xu, X. Wei, and L. Gao. The spatial distribution, accumulation and potential source of seldom monitored trace elements in sediments of Three Gorges Reservoir, China. Scientific Reports, 5(1):1-11, 2015.

[74] S. Tripathy and T. Praharaj. Delineation of Water and Sediment Contamination in River Near a Coal Ash Pond in Orissa, India. In Kenneth S. Sajwan, Irena Twardowska, Tracy Punshon, and Ashok K. Alva, editors, Coal Combustion Byproducts and Environmental Issues, pages 41-49. Springer, New York, 2006.

[75] P.K. Sahoo, S. Tripathy, M.K. Panigrahi, and S.M. Equeenuddin. Anthropogenic contamination and risk assessment of heavy metals in stream sediments influenced by acid mine drainage from a northeast coalfield, India. Bulletin of Engineering Geology and the Environment, 76(2):537-552, 2017.

[76] M. Singh, G. Müller, and I.B. Singh. Heavy metals in freshly deposited stream sediments of rivers associated with urbanisation of the Ganga Plain, India. Water, Air, and Soil Pollution, 141(1):35-54, 2002.

[77] D. Kim, J.H. Kim, S. Kang, M.S. Kim, and K.H. Shin. Assessment of Organic Matter Sources in the Singil Stream Flowing into Lake Shihwa, South Korea. Korean Journal of Ecology and Environment, 53(2):138-147, 2020.

[78] C.M. Iwegbue, F.O. Arimoro, G.E. Nwajei, and O.I. Eguavoen. Concentrations and distribution of trace metals in water and streambed sediments of Orogodo River, Southern Nigeria. Soil and Sediment Contamination: An International Journal, 21(3):382-406, 2012.

[79] M. Shahraki, M.H.M. Charaie, R. Moussavi-Harami, and A. Rashki. Geochemistry of Bandan River sediments in Sistan Basin (Eastern Iran): implication for provenance and environmental impact on the Hamoun Lake pollution. Environmental Earth Sciences, 80(1):1-17, 2021.

[80] S. Varkouhi. Geochemical evaluation of lead trace element in streambed sediments. In Proceeding of the WSEAS International Conference on Waste Management, Water pollution, Air Pollution, Indoor Climate, page 14-16, Arcachon, France, 2007.

[81] M. Okrusch and H.E. Frimmel. Sediments and sedimentary rocks. In Mineralogy: An Introduction to Minerals, Rocks, and Mineral Deposits, page 417-452. Springer, Berlin, Heidelberg, 2020.

[82] PhN Owens, RJ Batalla, AJ Collins, B Gomez, DM Hicks, AJ Horowitz, GM Kondolf, M Marden, MJ Page, DH Peacock, et al. Fine-grained sediment in river systems: environmental significance and management issues. River Research and Applications, 21(7):693-717, 2005. 
[83] PS Naden, JF Murphy, CH Old, J Newman, P Scarlett, M Harman, CP Duerdoth, A Hawczak, JL Pretty, A Arnold, et al. Understanding the controls on deposited fine sediment in the streams of agricultural catchments. Science of the Total Environment, 547:366-381, 2016.

[84] C. Wu, C. Ji, B. Shi, Y. Wang, J. Gao, Y. Yang, and J. Mu. The impact of climate change and human activities on streamflow and sediment load in the Pearl River basin. International Journal of Sediment Research, 34(4):307-321, 2019.

[85] D.E. Walling and B.W. Webb. Erosion and sediment yield: A global overview. In IAHS Publications - Series of Proceedings and Reports, volume 236, page 3-20. International Association of Hydrological Sciences, 1996.

[86] I. Twardowska, H.E. Allen, A.F. Kettrup, and W.J. Lacy. Solid waste: Assessment, monitoring and remediation. Elsevier, Oxford, UK, 2004.

[87] S.R. Chalov. Effects of placer mining on suspended sediment budget: case study of north of Russia's Kamchatka Peninsula. Hydrological Sciences Journal, 59(5):1081-1094, 2014.

[88] J. Krishnaswamy, M. Bunyan, V.K. Mehta, N. Jain, and K.U. Karanth. Impact of iron ore mining on suspended sediment response in a tropical catchment in Kudremukh, Western Chats, India. Forest Ecology and Management, 224(1-2):187-198, 2006.

[89] Janine Castro and Frank Reckendorf. Effects of sediment on the aquatic environment: Potential NRCS actions to improve aquatic habitat. US Department of Agriculture, Soil Conservation Service, 1995. https://www.nrcs.usda.gov/ wps/portal/nrcs/detail/national/ technical/?cid=nrcs143_014201.

[90] S.B. Kurniawan and M.F. Imron. Seasonal variation of plastic debris accumulation in the estuary of Wonorejo River, Surabaya, Indonesia. Environmental Technology \& Innovation, 16:100490, 2019.

[91] Xin-Feng Wei, Martin Bohlén, Catrin Lindblad, Mikael Hedenqvist, and Aron Hakonen. Microplastics generated from a biodegradable plastic in freshwater and seawater. Water Research, 198:117123, 2021.

[92] Martín CM Blettler, Elie Abrial, Farhan R Khan, Nuket Sivri, and Luis A Espinola. Freshwater plastic pollution: Recognizing research biases and identifying knowledge gaps. Water research, 143:416-424, 2018.

[93] P. Jacob, P. Kashyap, T. Suparat, and C. Visvanathan. Dealing with emerging waste streams: Used tyre assessment in Thailand using material flow analysis. Waste Management E Research, 32(9):918-926, 2014.
[94] W. Salomons, N.M. De Rooij, H. Kerdijk, and J. Bril. Sediments as a source for contaminants? Hydrobiologia, 149(1):13-30, 1987.

[95] H. Budzinski, I. Jones, J. Bellocq, C. Pierard, and P.H. Garrigues. Evaluation of sediment contamination by polycyclic aromatic hydrocarbons in the Gironde estuary. Marine Chemistry, 58(1-2):85-97, 1997.

[96] A. Lutgen, G. Jiang, N. Sienkiewicz, K. Mattern, J. Kan, and S. Inamdar. Nutrients and heavy metals in legacy sediments: concentrations, comparisons with upland soils, and implications for water quality. JAWRA Journal of the American Water Resources Association, 56(4):669-691, 2020.

[97] W.W. Stone, R.J. Gilliom, and K.R. Ryberg. Pesticides in US streams and rivers: Occurrence and trends during 1992-2011. Environmental Science E Technology, 48(19):11025-11030, 2014.

[98] U.S. McKnight, J.J. Rasmussen, B. Kronvang, P.J. Binning, and P.L. Bjerg. Sources, occurrence and predicted aquatic impact of legacy and contemporary pesticides in streams. Environmental Pollution, 200:64-76, 2015.

[99] F. Donnadieu, P. Besse-Hoggan, C. Forestier, and J. Artigas. Influence of streambed substratum composition on stream microbial communities exposed to the fungicide tebuconazole. Freshwater Biology, 61(12):2026-2036, 2016.

[100] A.E. Duncan, N. Vries, and K.B. Nyarko. Assessment of heavy metal pollution in the sediments of the River Pra and its tributaries. Water, Air, E Soil Pollution, 229(8):1-10, 2018.

[101] D.K. Makepeace, D.W. Smith, and S.J. Stanley. Urban stormwater quality: Summary of contaminant data. Critical Reviews in Environmental Science and Technology, 25(2):93-139, 1995.

[102] S.K. Frey, N. Gottschall, C. Wilkes, D.S. Grégoire, E. Topp, K.D.M. Pintar, M. Sunohara, R. Marti, and D.R. Lapen. Rainfall-induced runoff from exposed streambed sediments: An important source of water pollution. Journal of Environmental Quality, 44(1):236-247, 2015.

[103] J.J. Sansalone and S.C. Buchberger. Partitioning and first flush of metals in urban roadway storm water. Journal of Environmental Engineering, 123(2):134-143, 1997.

[104] Paul F. Rosenfeld and Lydia Feng. Risks of hazardous wastes. Elsevier, Oxford, UK, first edition, 2011.

[105] M. Petrovic, J. Radjenovic, C. Postigo, M. Kuster, M. Farre, M.L. Alda, and D. Barceló. Emerging contaminants in waste waters: Sources and occurrence. In D Barceló and $\mathrm{M}$ Petrovic, editors, Emerging contaminants from industrial and municipal waste, page 1-35. Springer, Berlin, Heidelberg, 2008. 
[106] W. Sanchez and E. Egea. Health and environmental risks associated with emerging pollutants and novel green processes. Environmental Science and Pollution Research, 25(7):6085-6086, 2018.

[107] S. Sauvé and M. Desrosiers. A review of what is an emerging contaminant. Chemistry Central Journal, 8(1):1-7, 2014.

[108] S.M. Elliott, M.E. Brigham, K.E. Lee, J.A. Banda, S.J. Choy, D.J. Gefell, T.A. Minarik, J.N. Moore, and Z.G. Jorgenson. Contaminants of emerging concern in tributaries to the Laurentian Great Lakes: I. Patterns of occurrence. PloS One, 12(9):0182868, 2017.

[109] Henar Margenat, Holly A Nel, Susa H Stonedahl, Stefan Krause, Francesc Sabater, and Jennifer D Drummond. Hydrologic controls on the accumulation of different sized microplastics in the streambed sediments downstream of a wastewater treatment plant (catalonia, spain). Environmental Research Letters, 16(11):115012, 2021.

[110] A.V. Jung, P. Le Cann, B. Roig, O. Thomas, E. Baurès, and M.F. Thomas. Microbial contamination detection in water resources: interest of current optical methods, trends and needs in the context of climate change. International Journal of Environmental Research and Public Health, 11(4):4292-4310, 2014.

[111] E. Páll, M. Niculae, T. Kiss, C.D. andru, and M. Spînu. Human impact on the microbiological water quality of the rivers. Journal of Medical Microbiology, 62(11):16351640, 2013.

[112] Hossain Md Anawar and Rezaul Chowdhury. Remediation of polluted river water by biological, chemical, ecological and engineering processes. Sustainability, 12(17), 2020.

[113] J Kenneth Bradshaw, Blake Snyder, David Spidle, Roy C. Sidle, Kathleen Sullivan, and Marirosa Molina. Sediment and Fecal Indicator Bacteria Loading in a Mixed Land Use Watershed: Contributions from Suspended Sediment and Bedload Transport. Journal of Environmental Quality, 50:598-611, 2021.

[114] Donna N Myers, GF Koltun, and Donna S Francy. Effects of hydrologic, biological, and environmental processes on sources and concentrations of fecal bacteria in the Cuyahoga River, with implications for management of recreational waters in Summit and Cuyahoga Counties, Ohio. Water-resources investigations report 98-4089, US Geological Survey, Columbus, OH, 1998.

[115] ET Riley and EE Prepas. Role of internal phosphorus loading in two shallow, productive lakes in alberta, canada. Canadian Journal of Fisheries and Aquatic Sciences, 41(6):845-855, 1984.

[116] JFH Shaw and EE Prepas. Temporal and spatial patterns of porewater phosphorus in shallow sediments, and its potential transport into narrow lake, alberta. Canadian Journal of Fisheries and Aquatic Sciences, 46(6):981-988, 1989.

[117] L.A. Kaplan and T.L. Bott. Diel fluctuations in bacterial activity on streambed substrata during vernal algal blooms: effects of temperature, water chemistry, and habitat. Limnology and Oceanography, 34(4):718-733, 1989.

[118] P.A. Ryan. Environmental effects of sediment on New Zealand streams: A review. New Zealand Journal of Marine and Freshwater Research, 25(2):207-221, 1991.

[119] A.J. Boulton. Hyporheic rehabilitation in rivers: Restoring vertical connectivity. Freshwater Biology, 52(4):632-650, 2007.

[120] M. Hartwig and D. Borchardt. Alteration of key hyporheic functions through biological and physical clogging along a nutrient and fine-sediment gradient. Ecohydrology, 8(5):961-975, 2015.

[121] S.R. Naganna, P.C. Deka, Sudheer. Ch, and W.F. Hansen. Factors influencing streambed hydraulic conductivity and their implications on stream-aquifer interaction: A conceptual review. Environmental Science and Pollution Research, 24(32):24765-24789, 2017.

[122] S. Krause, D.M. Hannah, J.H. Fleckenstein, C.M. Heppell, D. Kaeser, R. Pickup, G. Pinay, A.L. Robertson, and P.J. Wood. Inter-disciplinary perspectives on processes in the hyporheic zone. Ecohydrology, 4(4):481-499, 2011.

[123] A.P. Blaschke, K.H. Steiner, R. Schmalfuss, D. Gutknecht, and D. Sengschmitt. Clogging processes in hyporheic interstices of an impounded river, the Danube at Vienna, Austria. International Review of Hydrobiology, 88(34):397-413, 2003.

[124] A. Fox, A.I. Packman, F. Boano, C.B. Phillips, and S. Arnon. Interactions between suspended kaolinite deposition and hyporheic exchange flux under losing and gaining flow conditions. Geophysical Research Letters, 45(9):4077-4085, 2018.

[125] D.L. Karwan and J.E. Saiers. Hyporheic exchange and streambed filtration of suspended particles. Water Resources Research, 48(1), 2012.

[126] A.I. Packman and J.S. MacKay. Interplay of streamsubsurface exchange, clay particle deposition, and streambed evolution. Water Resources Research, 39(4), 2003.

[127] S. Shrivastava, M.J. Stewardson, and M. Arora. Distribution of clay-sized sediments in streambeds and influence of fine sediment clogging on hyporheic exchange. Hydrological Processes, 34(26):5674-5685, 2020. 
[128] Y. Teitelbaum, J. Dallmann, C.B. Phillips, A.I. Packman, R. Schumer, N.L. Sund, S.K. Hansen, and S. Arnon. Dynamics of hyporheic exchange flux and fine particle deposition under moving bedforms. Water Resources Research, 57(4):e2020WR028541, 2021.

[129] T.J. Hoellein, A.J. Shogren, J.L. Tank, P. Risteca, and J.J. Kelly. Microplastic deposition velocity in streams follows patterns for naturally occurring allochthonous particles. Scientific Reports, 9(1):3740, 2019.

[130] S. Frei, S. Piehl, B.S. Gilfedder, M.G.J. Löder, J. Krutzke, L. Wilhelm, and C. Laforsch. Occurence of microplastics in the hyporheic zone of rivers. Scientific Reports, 9(1):15256, 2019.

[131] N. Dikareva and K.S. Simon. Microplastic pollution in streams spanning an urbanisation gradient. Environmental Pollution, 250:292-299, 2019.

[132] V. Lahtela, M. Hyvärinen, and T. Kärki. Composition of plastic fractions in waste streams: Toward more efficient recycling and utilization. Polymers, 11(1):69, 2019.

[133] Hannah Ritchie and Max Roser. Plastic pollution. Our World in Data, 2018. https: / / ourworldindata. org/plastic-pollution.

[134] E.P. Rhodes, Z. Ren, and D.C. Mays. Zinc leaching from tire crumb rubber. Environmental Science \& Technology, 46(23):12856-12863, 2012.

[135] O.Z. Ojekunle, O.V. Ojekunle, A.A. Adeyemi, A.C. Taiwo, O.R. Sangowusi, A.M. Taiwo, and A.A. Adekitan. Evaluation of surface water quality indices and ecological risk assessment for heavy metals in scrap yard neighbourhood. SpringerPlus, 5(1):560, 2016.

[136] Fondriest Environmental Inc. Sediment transport and deposition. In Fundamentals of environmental measurements. 2014. https://www. fondriest. com/environmental-measurements/ parameters/hydrology/ sediment-transport-deposition/.

[137] G.M. Kondolf, Y. Gao, G.W. Annandale, G.L. Morris, E. Jiang, J. Zhang, Y. Cao, P. Carling, K. Fu, Q. Guo, and R. Hotchkiss. Sustainable sediment management in reservoirs and regulated rivers: Experiences from five continents. Earth's Future, 2(5):256-280, 2014.

[138] Gary Nichols. Sedimentology and stratigraphy. WileyBlackwell, UK, 2 edition, 2013.

[139] Peter J Talling, Douglas C Masson, Esther J Sumner, and Giuseppe Malgesini. Subaqueous sediment density flows: Depositional processes and deposit types. Sedimentology, 59(7):1937-2003, 2012.
[140] Boualem Remini, Djllali Bensafia, and Tahar Nasroun. Impact of sediment transport of the chellif river on silting of the boughezoul reservoir (algeria). Journal of Water and Land Development, (24):35-40, 2015.

[141] Tommaso Pacetti, Marco Lompi, Claudio Petri, and Enrica Caporali. Mining activity impacts on soil erodibility and reservoirs silting: Evaluation of mining decommissioning strategies. Journal of Hydrology, 589:125107, 2020.

[142] K.C. Taylor and P.N. Owens. Sediments in urban river basins: a review of sediment-contaminant dynamics in an environmental system conditioned by human activities. Journal of Soils and Sediments, 9(4):281-303, 2009.

[143] Magdalena Urbaniak, Marek Zieliski, Zbigniew Kaczkowski, and Maciej Zalewski. Spatial distribution of pcdds, pcdfs and dl-pcbs along the cascade of urban reservoirs. Hydrology Research, 44(4):614-630, 2013.

[144] Kathryn L Russell, Geoff J Vietz, and Tim D Fletcher. A suburban sediment budget: Coarse-grained sediment flux through hillslopes, stormwater systems and streams. Earth Surface Processes and Landforms, 44(13):26002614, 2019.

[145] P. Baveye, P. Vandevivere, B.L. Hoyle, P.C. DeLeo, and D.S. Lozada. Environmental impact and mechanisms of the biological clogging of saturated soils and aquifer materials. Critical Reviews in Environmental Science and Technology, 28(2):123-191, 1998.

[146] H. Bouwer. Artificial recharge of groundwater: Hydrogeology and Engineering. Hydrogeology Journal, 10(1):121-142, 2002.

[147] T. Bo, S. Fenoglio, C. Malacarne, M. Pessino, and F. Sgariboldi. Effects of clogging on stream macroinvertebrates: An experimental approach. Limnologica, 37(2):186-192, 2007.

[148] M. Brunke. Colmation and depth filtration within streambeds: Retention of particles in hyporheic interstices. International Review of Hydrobiology, 84(2):99-117, 1999.

[149] S. Descloux, T. Datry, and P. Marmonier. Benthic and hyporheic invertebrate assemblages along a gradient of increasing streambed colmation by fine sediment. Aquatic Sciences, 75(4):493-507, 2013.

[150] K.B. Suttle, M.E. Power, J.M. Levine, and C. McNeely. How fine sediment in riverbeds impairs growth and survival of juvenile salmonids. Ecological Applications, 14(4):969-974, 2004.

[151] J.I. Jones, J.F. Murphy, A.L. Collins, D.A. Sear, P.S. Naden, and P.D. Armitage. The impact of fine sediment on macro-invertebrates. River Research and Applications, 28(8):1055-1071, 2012. 
[152] P.J. Wood and P.D. Armitage. Biological effects of fine sediment in the lotic environment. Environmental Management, 21(2):203-217, 1997.

[153] Stephen J Davis, Per-Erik Mellander, Ann-Marie Kelly, Christoph D Matthaei, Jeremy J Piggott, Mary Kelly-Quinn, et al. Multiple-stressor effects of sediment, phosphorus and nitrogen on stream macroinvertebrate communities. Science of the Total Environment, 637:577-587, 2018.

[154] Hendrika J De Lange, Jolande De Jonge, Piet J Den Besten, Johan Oosterbaan, and Edwin T H M Peeters. Sediment pollution and predation affect structure and production of benthic macroinvertebrate communities in the RhineMeuse delta, The Netherlands. Journal of the North American Benthological Society, 23(3):557-579, 2004.

[155] A.N. Vadher, R. Stubbington, and P.J. Wood. Fine sediment reduces vertical migrations of Gammarus pulex (Crustacea: Amphipoda) in response to surface water loss. Hydrobiologia, 753(1):61-71, 2015.

[156] A.B. Sutherland and J.L. Meyer. Effects of increased suspended sediment on growth rate and gill condition of two southern Appalachian minnows. Environmental Biology of Fishes, 80(4):389-403, 2007.

[157] ML Lowe, MA Morrison, and RB Taylor. Harmful effects of sediment-induced turbidity on juvenile fish in estuaries. Marine Ecology Progress Series, 539:241-254, 2015.

[158] C. Soulsby, A.F. Youngson, H.J. Moir, and I.A. Malcolm. Fine sediment influence on salmonid spawning habitat in a lowland agricultural stream: A preliminary assessment. Science of the Total Environment, 265(13):295-307, 2001.

[159] F. Bona, A. Doretto, E. Falasco, V. La Morgia, E. Piano, R. Ajassa, and S. Fenoglio. Increased sediment loads in alpine streams: An integrated field study. River Research and Applications, 32(6):1316-1326, 2016.

[160] O. Izagirre, A. Serra, H. Guasch, and A. Elosegi. Effects of sediment deposition on periphytic biomass, photosynthetic activity and algal community structure. Science of the Total Environment, 407(21):5694-5700.

[161] J.I. Jones, A.L. Collins, P.S. Naden, and D.A. Sear. The relationship between fine sediment and macrophytes in rivers. River Research and Applications, 28(7):1006-1018, 2012.

[162] J.I. Jones, C.P. Duerdoth, A.L. Collins, P.S. Naden, and D.A. Sear. Interactions between diatoms and fine sediment. Hydrological Processes, 28(3):1226-1237, 2014.

[163] K.L. Parkhill and J.S. Gulliver. Effect of inorganic sediment on whole-stream productivity. Hydrobiologia, 472(1):5-17, 2002.
[164] R.J. Davies-Colley, C.W. Hickey, J.M. Quinn, and P.A. Ryan. Effects of clay discharges on streams. Hydrobiologia, 248(3):215-234, 1992.

[165] Judith S Weis. Improving microplastic research. AIMS Environmental Science, 6(5):326-340, 2019.

[166] Andrew JR Watts, Mauricio A Urbina, Rhys Goodhead, Julian Moger, Ceri Lewis, and Tamara S Galloway. Effect of microplastic on the gills of the shore crab carcinus maenas. Environmental Science E Technology, 50(10):53645369, 2016.

[167] Emma L Teuten, Steven J Rowland, Tamara S Galloway, and Richard C Thompson. Potential for plastics to transport hydrophobic contaminants. Environmental Science E Technology, 41(22):7759-7764, 2007.

[168] Anna Wegner, Ellen Besseling, Edwin M Foekema, $P$ Kamermans, and Albert A Koelmans. Effects of nanopolystyrene on the feeding behavior of the blue mussel (mytilus edulis I.). Environmental Toxicology and Chemistry, 31(11):2490-2497, 2012.

[169] María F Ríos, Rodrigo D Hernández-Moresino, and David E Galván. Assessing urban microplastic pollution in a benthic habitat of patagonia argentina. Marine Pollution Bulletin, 159:111491, 2020.

[170] Wei Huang, Biao Song, Jie Liang, Qiuya Niu, Guangming Zeng, Maocai Shen, Jiaqin Deng, Yuan Luo, Xiaofeng Wen, and Yafei Zhang. Microplastics and associated contaminants in the aquatic environment: A review on their ecotoxicological effects, trophic transfer, and potential impacts to human health. Journal of Hazardous Materials, 405:124187, 2021.

[171] T. Van Emmerik and A. Schwarz. Plastic debris in rivers. Wiley Interdisciplinary Reviews: Water, 7(1):1398, 2020.

[172] Gary Beasley and Pauline E. Kneale. Reviewing the impact of metals and $\mathrm{PAHs}$ on macroinvertebrates in urban watercourses. Progress in Physical Geography, 26(2):236-270, 2002.

[173] T. Bere, T. Dalu, and T. Mwedzi. Detecting the impact of heavy metal contaminated sediment on benthic macroinvertebrate communities in tropical streams. Science of The Total Environment, 572:147-156.

[174] L.A. Courtney and W.H. Clements. Assessing the in fluence of water and substratum quality on benthic macroinvertebrate communities in a metal-polluted stream: An experimental approach. Freshwater Biology, 47(9):1766-1778, 2002.

[175] C.W. Hickey and W.H. Clements. Effects of heavy metals on benthic macroinvertebrate communities in New Zealand streams. Environmental Toxicology and Chemistry: An International Journal, 17(11):2338-2346, 1998. 
[176] P.W. Moran, L.H. Nowell, N.E. Kemble, B.J. Mahler, I.R. Waite, and P.C. Van Metre. Influence of sediment chemistry and sediment toxicity on macroinvertebrate communities across 99 wadable streams of the Midwestern USA. Science of the Total Environment, 599:1469-1478, 2017.

[177] V. Pettigrove and A. Hoffmann. A field-based microcosm method to assess the effects of polluted urban stream sediments on aquatic macroinvertebrates. Environmental Toxicology and Chemistry: An International Journal, 24(1):170-180, 2005.

[178] Gordana Devi, Sanja Sakan, and Dragana Đorevi. Assessment of the environmental significance of nutrients and heavy metal pollution in the river network of serbia. Environmental Science and Pollution Research, 23(1):282297, 2016.

[179] Emmanuel O Akindele, Omobukola D Omisakin, Oluwagbemiga A Oni, Olanrewaju O Aliu, Gbenga E Omoniyi, and Oluwaseun T Akinpelu. Heavy metal toxicity in the water column and benthic sediments of a degraded tropical stream. Ecotoxicology and Environmental Safety, 190:110153, 2020.

[180] Tatenda Dalu, Ryan J Wasserman, Mandla L Magoro, Tongayi Mwedzi, P William Froneman, and Olaf LF Weyl. Variation partitioning of benthic diatom community matrices: Effects of multiple variables on benthic diatom communities in an austral temperate river system. Science of the Total Environment, 601:73-82, 2017.

[181] F.J. Burdon, N.A. Munz, M. Reyes, A. Focks, A. Joss, K. Räsänen, F. Altermatt, R.I.L. Eggen, and C. Stamm. Agriculture versus wastewater pollution as drivers of macroinvertebrate community structure in streams. Science of the Total Environment, 659:1256-1265, 2019.

[182] M. Ricart, H. Guasch, D. Barceló, R. Brix, M.H. Conceição, A. Geiszinger, M.J.L. Alda, J.C. López-Doval, I. Muñoz, C. Postigo, and A.M. Romaní. Primary and complex stressors in polluted Mediterranean rivers: Pesticide effects on biological communities. Journal of Hydrology, 383(12):52-61, 2010.

[183] R.B. Schäfer. Responses of freshwater macroinvertebrates to pesticides: Insights from field studies. Current Opinion in Environmental Science Er Health, 11:1-7, 2019.

[184] Sharanjeet Kaur Kahlon, Gaurav Sharma, JM Julka, Amit Kumar, Shweta Sharma, and Florian J Stadler. Impact of heavy metals and nanoparticles on aquatic biota. Environmental Chemistry Letters, 16(3):919-946, 2018.

[185] SÖNMEZ Girgin, N Kazanci, and M Dügel. Relationship between aquatic insects and heavy metals in an urban stream using multivariate techniques. International Journal of Environmental Science E Technology, 7(4):653-664, 2010.
[186] William H Clements. Community responses of stream organisms to heavy metals: a review of observational and experimental approaches. In Michael C. Newman and Alan W Mclntosh, editors, Metal Ecotoxicology, pages 363-391. CRC Press, Boca Raton, 2020.

[187] H. Liao, J.Y. Yen, Y. Guan, D. Ke, and C. Liu. Differential responses of stream water and bed sediment microbial communities to watershed degradation. Environment International, 134:105198, 2020.

[188] E.A. Okoye, B. Bocca, F. Ruggieri, A.N. Ezejiofor, I.L. Nwaogazie, J.L. Domingo, J. Rovira, C. Frazzoli, and O.E. Orisakwe. Metal pollution of soil, plants, feed and food in the Niger Delta, Nigeria: Health risk assessment through meat and fish consumption. Environmental Research, 198:111273, 2021.

[189] M.N.O. Ajima, P.C. Nnodi, O.A. Ogo, G.S. Adaka, D.I. Osuigwe, and D.C. Njoku. Bioaccumulation of heavy metals in Mbaa River and the impact on aquatic ecosystem. Environmental Monitoring and Assessment, 187(12):1-9, 2015.

[190] N. Geng, Y. Wu, M. Zhang, D.C. Tsang, J. Rinklebe, Y. Xia, D. Lu, L. Zhu, K.N. Palansooriya, K.H. Kim, and Y.S. Ok. Bioaccumulation of potentially toxic elements by submerged plants and biofilms: A critical review. Environment International, 131:105015, 2019.

[191] M. Nair, K.V. Jayalakshmy, K.K. Balachandran, and T. Joseph. Bioaccumulation of toxic metals by fish in a semi-enclosed tropical ecosystem. Environmental Forensics, 7(3):197-206, 2006.

[192] A. Santoro, G. Blo, S. Mastrolitti, and F. Fagioli. Bioaccumulation of heavy metals by aquatic macroinvertebrates along the Basento River in the south of Italy. Water, air, and soil pollution, 201(1):19-31, 2009.

[193] M.T.K. Tsui, J.C. Finlay, and E.A. Nater. Mercury bioaccumulation in a stream network. Environmental Science $\mathcal{E}$ Technology, 43(18):7016-7022, 2009.

[194] N. Durães, L.A. Novo, C. Candeias, and E.F. Da Silva. Distribution, transport and fate of pollutants. In Soil Pollution, page 29-57. Academic Press, 2018.

[195] T.A. Schlacher, B. Liddell, T.F. Gaston, and M. SchlacherHoenlinger. Fish track wastewater pollution to estuaries. Oecologia, 144(4):570-584, 2005.

[196] T. Ikemoto, N.P.C. Tu, N. Okuda, A. Iwata, K. Omori, S. Tanabe, B.C. Tuyen, and I. Takeuchi. Biomagnification of trace elements in the aquatic food web in the Mekong Delta, South Vietnam using stable carbon and nitrogen isotope analysis. Archives of Environmental Contamination and Toxicology, 54(3):504-515, 2008. 
[197] M.R. Quinn, X. Feng, C.L. Folt, and C.P. Chamberlain. Analyzing trophic transfer of metals in stream food webs using nitrogen isotopes. Science of the Total Environment, 317(1-3):73-89, 2003.

[198] P.K. Pandey, M.L. Soupir, and C.R. Rehmann. A model for predicting resuspension of Escherichia coli from streambed sediments. Water Research, 46(1):115-126, 2012.

[199] G. Nogaro, T. Datry, F. Mermillod-Blondin, S. Descloux, and B. Montuelle. Influence of streambed sediment clogging on microbial processes in the hyporheic zone. Freshwater Biology, 55(6):1288-1302, 2010.

[200] Cristiane Q Surbeck, F Douglas Shields Jr, and Alexandra M Cooper. Fecal indicator bacteria entrainment from streambed to water column: Transport by unsteady flow over a sand bed. Journal of Environmental Quality, 45(3):1046-1053, 2016.

[201] Yingrong Wen, Gerrit Schoups, and Nick Van De Giesen. Organic pollution of rivers: Combined threats of urbanization, livestock farming and global climate change. Scientific Reports, 7(1):1-9, 2017.

[202] P.L. Dangi, B.K. Sharma, and B. Uppadhyay. BOD, total and faecal coliforms bacterial status of Lake Pichhola, Udaipur, Rajasthan. International Journal of Fisheries and Aquatic Studies, 5(3):176-180, 2017.

[203] A. Beyer, D. Mackay, M. Matthies, F. Wania, and Webster. Assessing long-range transport potential of persistent organic pollutants. Environmental Science E Technology, 34(4):699-703, 2000.

[204] R. Jamieson, D.M. Joy, H. Lee, R. Kostaschuk, and R. Gordon. Transport and deposition of sediment-associated Escherichia coli in natural streams. Water Research, 39(12):2665-2675, 2005.

[205] H. Fischer, M. Pusch, and J. Schwoerbel. Spatial distribution and respiration of bacteria in stream-bed sediments. Archiv für Hydrobiologie, 137(3):281-300, 1996.

[206] M.B. Cardenas and V.A. Zlotnik. Three-dimensional model of modern channel bend deposits. Water Resources Research, 39(6), 2003.

[207] J. Levy, M.D. Birck, S. Mutiti, K.C. Kilroy, B. Windeler, O. Idris, and L.N. Allen. The impact of storm events on a riverbed system and its hydraulic conductivity at a site of induced infiltration. Journal of Environmental Management, 92(8):1960-1971, 2011.

[208] P.E. Lisenby, K.A. Fryirs, and C.J. Thompson. River sensitivity and sediment connectivity as tools for assessing future geomorphic channel behavior. International Journal of River Basin Management, 18(3):279-293, 2020.
[209] J.L. Florsheim, J.F. Mount, and A. Chin. Bank erosion as a desirable attribute of rivers. BioScience, 58(6):519-529, 2008.

[210] Kathy A. Shade. Temporal analysis of floodplain deposition using urban pollution stratigraphy. Master's thesis, Missouri State University, Wilson Creek, SW Missouri, 2003. https://bearworks.missouristate. edu/theses/2071.

[211] C. Chen, A.I. Packman, and J.F. Gaillard. Pore-scale analysis of permeability reduction resulting from colloid deposition. Geophysical Research Letters, 35(7), 2008.

[212] K. Kaffas and V. Hrissanthou. Soil erosion, streambed deposition and streambed erosion-assessment at the mountainous terrain. Proceedings, 2(11):626, 2018.

[213] A.E. Tufo, S. Vázquez, N.F. Porzionato, M.C. Grimolizzi, M.B. Prados, M. Sica, and G. Curutchet. Contamination alters the physicochemical and textural characteristics of clays in the sediments of the peri urban Reconquista River, affecting the associated indigenous microorganisms. Minerals, 11(3):242, 2021.

[214] J.O. Dickson, M.A. Mayes, S.C. Brooks, T.L. Mehlhorn, K.A. Lowe, J.K. Earles, L. Goñez-Rodriguez, D.B. Watson, and M.J. Peterson. Source relationships between streambank soils and streambed sediments in a mercurycontaminated stream. Journal of Soils and Sediments, 19(4):2007-2019, 2019.

[215] G. De Giudici, C. Pusceddu, D. Medas, C. Meneghini, A. Gianoncelli, V. Rimondi, F. Podda, R. Cidu, P. Lattanzi, R.B. Wanty, and B.A. Kimball. The role of natural biogeochemical barriers in limiting metal loading to a stream affected by mine drainage. Applied Ceochemistry, 76:124-135, 2017.

[216] Jasmin Fetzer, Markus Holzner, Michael Plötze, and Gerhard Furrer. Clogging of an alpine streambed by silt-sized particles-insights from laboratory and field experiments. Water Research, 126:60-69, 2017.

[217] Yang Xian, Menggui Jin, Hongbin Zhan, and Yanfeng Liu. Reactive transport of nutrients and bioclogging during dynamic disconnection process of stream and groundwater. Water Resources Research, 55(5):38823903, 2019.

[218] C. Gu, G.M. Hornberger, A.L. Mills, J.S. Herman, and S.A. Flewelling. Nitrate reduction in streambed sediments: Effects of flow and biogeochemical kinetics. Water Resources Research, 43(12), 2007.

[219] H.S. Galavotti. Spatial profiles of sediment denitrification at the ground water-surface water interface in Cobb Mill Creek on the Eastern Shore of Uirginia. PhD thesis, University of Virginia, Charlottesville, Virginia, 2004. 
[220] J.B. Jones and P.J. Mulholland. Streams and ground waters. Academic Press, San Diego, 1999.

[221] C. Wang, M.A. Briggs, F.D. Day-Lewis, and L.D. Slater. Evaluation of riverbed magnetic susceptibility for mapping biogeochemical hot spots in groundwater-impacted rivers. Hydrological Processes, 35(5):14184, 2021.

[222] Paul Romeijn, Sophie A Comer-Warner, Sami Ullah, David M Hannah, and Stefan Krause. Streambed organic matter controls on carbon dioxide and methane emissions from streams. Environmental Science E Technology, 53(5):2364-2374, 2019.

[223] G. Wharton, S.H. Mohajeri, and M. Righetti. The pernicious problem of streambed colmation: A multidisciplinary reflection on the mechanisms, causes, impacts, and management challenges. Wiley Interdisciplinary Reviews: Water, 4(5):1231, 2017.

[224] F. Boano, J.W. Harvey, A. Marion, A.I. Packman, R. Revelli, L. Ridolfi, and A. Wörman. Hyporheic flow and transport processes: Mechanisms, models, and biogeochemical implications. Reviews of Geophysics, 52(4):603-679, 2014.

[225] I. Peralta-Maraver, J. Reiss, and A.L. Robertson. Interplay of hydrology, community ecology and pollutant attenuation in the hyporheic zone. Science of the Total Environment, 610:267-275, 2018.

[226] V. Novotny and J.W. Witte. Ascertaining aquatic ecological risks of urban stormwater discharges. Water Research, 31(10):2573-2585, 1997.

[227] K. Schilling and M. Zessner. Foam in the aquatic environment. Water research, 45(15):4355-4366, 2011.

[228] Erinn Richmond, Michael R. Grace, John R. Kelly, Andrew Reisinger, Emma J. Rosi, and David M. Walters. Pharmaceuticals and personal care products (PPCPs) are ecological disrupting compounds (EcoDC). Elementa: Science of the Anthropocene, 5:1-8, 2017.

[229] T. Brodin, S. Piovano, J. Fick, J. Klaminder, M. Heynen, and M. Jonsson. Ecological effects of pharmaceuticals in aquatic systems-impacts through behavioural alterations. Philosophical Transactions of the Royal Society B: Biological Sciences, 369(1656):20130580, 2014.

[230] A. Zenker, M.R. Cicero, F. Prestinaci, P. Bottoni, and M. Carere. Bioaccumulation and biomagnification potential of pharmaceuticals with a focus to the aquatic environment. Journal of Environmental Management, 133:378-387, 2014.

[231] D. Minchin. The transport and the spread of living aquatic species. In The ecology of transportation: Managing mobility for the environment, page 77-97. Springer, Dordrecht, 2006.
[232] Linda M Ziccardi, Aaron Edgington, Karyn Hentz, Konrad J Kulacki, and Susan Kane Driscoll. Microplastics as vectors for bioaccumulation of hydrophobic organic chemicals in the marine environment: A state-of-thescience review. Environmental Toxicology and Chemistry, 35(7):1667-1676, 2016.

[233] Samuel N Luoma and Philip S Rainbow. Why is metal bioaccumulation so variable? biodynamics as a unifying concept. Environmental Science \& Technology, 39(7):1921-1931, 2005.

[234] Burton Jr G.A. Assessing the toxicity of freshwater sediments. Environmental Toxicology and Chemistry: An International Journal, 10(12):1585-1627, 1991.

[235] R.J. Wenning, G.E. Batley, C.G. Ingersoll, and D.W. Moore. Use of sediment quality guidelines and related tools for the assessment of contaminated sediments. SETAC Press, FL, USA, 2005.

[236] Robin Brinkmeyer, Rainer MW Amon, John R Schwarz, Tara Saxton, Dustin Roberts, Sarah Harrison, Nicholas Ellis, Jessica Fox, Katherine DiGuardi, Mona Hochman, et al. Distribution and persistence of Escherichia coli and Enterococci in stream bed and bank sediments from two urban streams in Houston, TX. Science of the Total Environment, 502:650-658, 2015.

[237] Anna Lintern, Paul J Leahy, Atun Zawadzki, Patricia Gadd, Henk Heijnis, Geraldine Jacobsen, Simon Connor, Ana Deletic, and David T McCarthy. Sediment cores as archives of historical changes in floodplain lake hydrology. Science of the Total Environment, 544:1008-1019, 2016.

[238] R. Chester, J.H. Stoner, Epps L., Diab T., G., and J. Hathaway. $\mathrm{Pb}$ in particulates from the lower atmosphere of the eastern Atlantic. Nature, 245:27-28, 1973.

[239] B. Rubio, M.A. Nombela, and F. Vilas. Geochemistry of major and trace elements in sediments of the Ria de Vigo (NW Spain): an assessment of metal pollution. Marine Pollution Bulletin, 40(11):968-980, 2000.

[240] D.L. Tomlinson, J.G. Wilson, C.R. Harris, and D.W. Jeffrey. Problems in the assessment of heavy-metal levels in estuaries and the formation of a pollution index. Helgoländer Meeresuntersuchungen, 33(1-4):566-575, 1980.

[241] G. Muller. Index of geoaccumulation in sediments of the Rhine River. Geology Journal, 2:109-118, 1969.

[242] R.A. Sutherland. Bed sediment-associated trace metals in an urban stream, Oahu, Hawaii. Environmental Geology, 39(6):611-627, 2000. 
[243] A.K. Baldwin, S.R. Corsi, M.A. Lutz, C.G. Ingersoll, R. Dorman, C. Magruder, and M. Magruder. Primary sources and toxicity of PAHs in Milwaukee-area streambed sediment. Environmental Toxicology and Chemistry, 36(6):1622-1635, 2017.

[244] Stefania Gheorghe, Catalina Stoica, Gabriela Geanina Vasile, Mihai Nita-Lazar, Elena Stanescu, and Irina Eugenia Lucaciu. Metals toxic effects in aquatic ecosystems: Modulators of water quality. In Hlanganani Tutu, editor, Water Quality, chapter 4. IntechOpen, Rijeka, 2017.

[245] B.J. Mahler, T.S. Schmidt, L.H. Nowell, S.L. Qi, P.C. Van Metre, M.L. Hladik, D.M. Carlisle, M.D. Munn, and J. May. Biofilms provide new insight into pesticide occurrence in streams and links to aquatic ecological communities. Environmental Science E Technology, 54(9):5509-5519, 2020.

[246] C.J.F. Ter Braak. Partial canonical correspondence analysis. In Classification and related methods of data analysis: Proceedings of the first conference of the International Federation of Classification Societies (IFCS), page 551-558, North-Holland, 1988. Technical University of Aachen.

[247] P Gbolo and P Gerla. Statistical analysis to characterize transport of nutrients in groundwater near an abandoned feedlot. Hydrology and Earth System Sciences, 17(12):4897-4906, 2013.

[248] Prosper Cbolo and Dina L Lopez. Analysis of trace elements pollution within streambed sediments from the shade river watershed, southeastern ohio. Environmental Earth Sciences, 73(11):7193-7204, 2015.

[249] Dick De Zwart and Leo Posthuma. Complex mixture toxicity for single and multiple species: proposed methodologies. Environmental Toxicology and Chemistry, 24(10):2665-2676, 2005.

[250] Jiaqi Wang, Leonie S Lautz, Tom M Nolte, Leo Posthuma, K Remon Koopman, Rob SEW Leuven, and A Jan Hendriks. Towards a systematic method for assessing the impact of chemical pollution on ecosystem services of water systems. Journal of Environmental Management, 281:111873, 2021.

[251] R Srinivas, Ajit Pratap Singh, Ayush Aman Gupta, and Piyush Kumar. Holistic approach for quantification and identification of pollutant sources of a river basin by analyzing the open drains using an advanced multivariate clustering. Environmental Monitoring and Assessment, 190(12):1-24, 2018.

[252] R.D. Fox. Physical/chemical treatment of organically contaminated soils and sediments. Journal of the Air $\mathcal{E}$ Waste Management Association, 46(5):391-413, 1996.

[253] R.W. Lammers and B.P. Bledsoe. What role does stream restoration play in nutrient management? Critical Reviews in Environmental Science and Technology, 47(6):335-371, 2017.
[254] Marianne Olsen, Karina Petersen, Alizee P. Lehoux, Matti Leppänen, Morten Schaanning, Ian Snowball, Sigurd $\emptyset x n e v a d$, and Espen Lund. Contaminated Sediments : Review of solutions for protecting aquatic environments. Nordisk Ministerråd, Copenhagen, 2019.

[255] Joshua N. Edokpayi, John O. Odiyo, and Olatunde S. Durowoju. Impact of Wastewater on Surface Water Quality in Developing Countries: A Case Study of South Africa. In Hlanganani Tutu, editor, Water Quality, chapter 18. IntechOpen, Rijeka, 2017.

[256] T. Rasheed, M. Bilal, F. Nabeel, M. Adeel, and H.M. Iqbal. Environmentally-related contaminants of high concern: Potential sources and analytical modalities for detection, quantification, and treatment. Environment International, 122:52-66, 2019.

[257] D.X. Wang, N.E. Abriak, R. Zentar, and W. Xu. Solidification/stabilization of dredged marine sediments for road construction. Environmental Technology, 33(1):95-101, 2012.

[258] V.S. Magar, D.B. Chadwick, T.S. Bridges, P.C. Fuchsman, J.M. Conder, T.J. Dekker, J.A. Steevens, K.E. Gustavson, and M.A. Mills. Monitored natural recovery at contaminated sediment sites. ESTCP Project ER-0622, Environ International Corp., Arlington, VA, 2009. https://clu-in.org/ download/contaminantfocus/sediments/ ER-0622-MNR-FR.pdf.

[259] C. Berenbrock and A.W. Tranmer. Simulation of flow, sediment transport, and sediment mobility of the lower Coeur d'Alene River, Idaho. Scientific investigations report 2008-5093, US Geological Survey, Reston, VA, 2008.

[260] I. Robles, J. Lakatos, P. Scharek, Z. Planck, G. Hernández, S. Solís, and E. Bustos. Characterization and remediation of soils and sediments polluted with mercury: Occurrence, transformations, environmental considerations and san joaquin's sierra gorda case. In Maria C. Hernandez-Soriano, editor, Environmental Risk Assessment of Soil Contamination, chapter 29. IntechOpen, Rijeka, 2014.

[261] Yuying Zhang, Claudia Labianca, Liang Chen, Sabino De Gisi, Michele Notarnicola, Binglin Guo, Jian Sun, Shiming Ding, and Lei Wang. Sustainable ex-situ remediation of contaminated sediment: A review. Environmental Pollution, 287:117333, 2021.

[262] WEDA. Reservoir dredging: A practical overview. WEDA's Technical Report, 2021. Available online: wwW . westerndredging. org. 
[263] I.H. Kantrowitz and W.M. Woodham. Efficiency of a stormwater detention pond in reducing loads of chemical and physical constituents in urban streamflow. Water-resources investigations report 94-4217, US Geological Survey, FL, 1995.

[264] D.W. Stanley. Pollutant removal by a stormwater dry detention pond. Water Environment Research, 68(6):1076-1083, 1996.

[265] J. Botting and K. Bellette. Stormwater Pollution Prevention - Code of Practice for Local, State, and Federal Government. Environment Protection Authority, Adelaide, 1998.

[266] V. Sheoran and A. Sheoran. Biotechnological aspects of soil decontamination. In Biotechnologies and Biomimetics for Civil Engineering, page 373-410. Springer, Cham, 2015.

[267] D.W. Himmelheber and J.B. Hughes. In situ biotransformation of contaminants in sediments. In Processes, Assessment and Remediation of Contaminated Sediments, page 263-304. Springer, New York, 2014.

[268] J.G. Watson. Physical/chemical treatment of organically contaminated soils and sediments. Journal of the Air E Waste Management Association, 46(10):993-1003, 1996.

[269] Susan E Finger, Stanley E Church, and David A Nimick. Evaluating the success of remediation in the boulder river watershed. Professional paper 1652-f, US Geological Survey, Denver, CO, 2004. https://pubs . usgs.gov/pp/2004/1652/pdf/ChapF.pdf.

[270] Stephanie Parkyn, Kevin Collier, Joanne Clapcott, Bruno David, Rob Davies-Colley, Fleur Matheson, John Quinn, William Shaw, and Richard Storey. The restoration indicator toolkit: Indicators for monitoring the ecological success of stream restoration. Technical report, National Institute of Water Atmospheric Research Ltd., Hamilton, New Zealand, 2010. https : / / www . envirolink. govt.nz/assets/Envirolink/

RestorationIndicatorToolkit-stream. pdf.

[271] Susan E Finger, Stanley E Church, and Paul von Guerard. Potential for successful ecological remediation, restoration, and monitoring. Professional paper 1651, US Geological Survey, San Juan County, Colorado, 2007. https: / / pubs . usgs.gov/pp/1651/downloads / Vol2_combinedChapters/vol2_chapF.pdf.

[272] Sharon L Gelinas and Robert Tupling. Monitoring remediation? Have mine-waste and mill-tailings removal and flood-plain restoration been successful in the High Ore Creek valley. Professional paper 1652-e2, US Geological Survey, Reston, VA, 2004. https : / / pubs . usgs . gov/pp/2004/1652/pdf/ChapE2.pdf. 
Table 1. Types and sources of chemical streambed pollutants.

\begin{tabular}{|c|c|c|c|}
\hline Pollutants & Common sources & Potential adverse effects on environment & References \\
\hline $\begin{array}{l}\text { Pollutants from urban } \\
\text { runoff: } \\
\text { - Road dust particles, } \\
\text { - Oil and tar } \\
\text { products, } \\
\text { - Residuals from } \\
\text { petrol and oil spills } \\
\text { such as dioxins, } \\
\text { hydrocarbons, } \\
\text { halogenated } \\
\text { phenols and } \\
\text { oxygenated } \\
\text { compounds, } \\
\text { - Tyre deterioration } \\
\text { products } \\
\text { - Asbestos } \\
\text { - Heavy metals such } \\
\text { as Cadmium, } \\
\text { Chromium, Copper, } \\
\text { Iron } \\
\text { - De-icing salts }\end{array}$ & $\begin{array}{l}\text { Road and vehicular } \\
\text { related emissions; Wear } \\
\text { of tyres and brake } \\
\text { linings; Road runoff } \\
\text { during storm events }\end{array}$ & $\begin{array}{l}\text { - Hydrocarbons and heavy metals could adversely } \\
\text { affect reproduction and bring behavioural changes } \\
\text { of aquatic life under long-term exposure. } \\
\text { - Direct toxic effect on fishes and aquatic organisms } \\
\text { (due to epilithic algae and detritus) } \\
\text { - Create subtle changes in the enzyme activity and } \\
\text { growth rates in macro-invertebrates. } \\
\text { - Can persist and settle at the bottom of the water } \\
\text { column and affect the benthic organisms }\end{array}$ & {$[26,27,103]$} \\
\hline $\begin{array}{l}\text { Discharge of } \\
\text { Secondary effluents } \\
\text { (heavy metals) such as } \\
\text { arsenic, cadmium, } \\
\text { copper, lead, nickel } \\
\text { and zinc }\end{array}$ & $\begin{array}{l}\text { Industrial wastewater, } \\
\text { flushing of corroded } \\
\text { metals, fertilizer runoff } \\
\text { and outwash deposits } \\
\text { holding wear and tear } \\
\text { wastes of engine } \\
\text { moving parts }\end{array}$ & $\begin{array}{l}\text { - Can become persistent in the environment } \\
\text { (generally do not degrade easily) } \\
\text { - Decay and volatilize into lethal products by } \\
\text { photolysis } \\
\text { - Cause sub-lethal effects and potential harm on } \\
\text { aquatic organisms and dependent food chain } \\
\text { (birds and mammals) } \\
\text { - Groundwater and soil contamination } \\
\text { - Bio-accumulate and threaten predators and } \\
\text { humans at the top of the food chain. }\end{array}$ & {$[101,203,226]$} \\
\hline $\begin{array}{l}\text { Pesticides: } \\
\text { - Organochloride } \\
\text { pesticides such as } \\
\text { DDT, chlordane and } \\
\text { dieldrin. } \\
\text { - Herbicides such as } \\
\text { dacthal, diuron, } \\
\text { dicamba, trifluralin } \\
\text { and linuron, } \\
\text { trichlorocarbon. } \\
\text { - Insecticides such as } \\
\text { endosulfan, lindane, } \\
\text { dicofol, fipronil and } \\
\text { chlorpyrifos. } \\
\text { - Fungicides and } \\
\text { wood preservatives } \\
\text { such as dichlone, } \\
\text { pentachlorophenol } \\
\text { and PCNB }\end{array}$ & $\begin{array}{l}\text { Runoff from agricultural } \\
\text { fields, lawns and } \\
\text { gardens; } \\
\text { Erosion of soils from } \\
\text { previously } \\
\text { contaminated sites; } \\
\text { Atmospheric deposition; } \\
\text { Waste water discharge } \\
\text { from treatment and } \\
\text { disposal facilities; } \\
\text { Spills from } \\
\text { manufacturing and } \\
\text { transport-mixing- } \\
\text { loading facilities. }\end{array}$ & $\begin{array}{l}\text { - Contamination of river system components which } \\
\text { supports drinking water requirements and } \\
\text { irrigation } \\
\text { - Acute impacts on the benthic biota such as clams } \\
\text { and insects which are commonly consumed by } \\
\text { fish. } \\
\text { - Adverse effects on aquatic biota and associated } \\
\text { ecosystems and fish-eating wildlife } \\
\text { - Long-term exposure causes endocrine disruptive } \\
\text { effects in addition to impediment of growth and } \\
\text { reproduction of exposed organisms. }\end{array}$ & {$[24,97]$} \\
\hline
\end{tabular}




\begin{tabular}{|c|c|c|c|}
\hline $\begin{array}{l}\text { Emerging } \\
\text { Eontaminants (EC): } \\
\text { Emerging organic } \\
\text { compounds mostly } \\
\text { consisting of } \\
\text { pharmaceuticals } \\
\text { and their degraded } \\
\text { products. } \\
\text { Hormones such as } \\
\text { estrogen 17ß } \\
\text { estradiol, and other } \\
\text { natural hormones } \\
\text { such as estrone and } \\
\text { estriol. } \\
\text { New class of } \\
\text { pesticides such as } \\
\text { Neonicotinoids, and } \\
\text { chemicals such as } \\
\text { bis(2-ethylhexyl) } \\
\text { phthalate and } \\
\text { dichlorvos. } \\
\text { Chemicals such as } \\
\text { Poly Carbonated } \\
\text { Biphenyls (PCBs) } \\
\text { and Poly } \\
\text { Fluorinated Alkyl } \\
\text { substances. } \\
\text { Micro- and Nano- } \\
\text { plastics, } \\
\text { Flame retardants, } \\
\text { Cosmetics such as } \\
\text { Benzophenones, } \\
\text { Plasticizers such as } \\
\text { Phenolic } \\
\text { compounds (e.g. } \\
\text { Bisphenol A and } \\
\text { Octylphenol) and } \\
\text { Phthalates (e.g. } \\
\text { Di(2-ethylhexyl) } \\
\text { phthalate and } \\
\text { Dimethyl phthalate) } \\
\text { Contraceptives }\end{array}$ & $\begin{array}{l}\text { Discharge of } \\
\text { pharmaceutical } \\
\text { residues, personal care } \\
\text { products, surfactants; } \\
\text { Discharge of untreated } \\
\text { and partially treated } \\
\text { industrial and domestic } \\
\text { effluents; } \\
\text { Runoff from agricultural } \\
\text { and urban catchments. }\end{array}$ & $\begin{array}{l}\text { - Adverse effects such as developmental } \\
\text { inhibitions, behaviour alteration and endocrine } \\
\text { disruption on aquatic organisms (such as } \\
\text { prokaryotes, protists and invertebrates) and } \\
\text { associated wildlife. } \\
\text { - Some of the EC compounds are hydrophobic, bio- } \\
\text { accumulative and persistent which could affect } \\
\text { benthic and aquatic biota (plants such as water } \\
\text { hyacinths) } \\
\text { - Groundwater, stream water and soil } \\
\text { contamination } \\
\text { - Cause serious effects on humans including a wide } \\
\text { range of cancers, heart and kidney failure. } \\
\text { - Potential genetic mutation in organisms with } \\
\text { long-term exposure. }\end{array}$ & $\begin{array}{l}{[29,51,105,} \\
107,108]\end{array}$ \\
\hline
\end{tabular}


Table 2: Indices for assessing streambed pollution by heavy metals

\begin{tabular}{|c|c|c|c|c|}
\hline Indices & Definition & Limiting values & Information & References \\
\hline $\begin{array}{l}\text { Enrichment } \\
\text { factor (EF) }\end{array}$ & $\begin{array}{l}\text { Ratio of an element } \\
\text { concentration to a } \\
\text { reference element in a } \\
\text { given sample divided } \\
\text { by the ratio of an } \\
\text { element concentration } \\
\text { to a reference element } \\
\text { in the crust }\end{array}$ & $\begin{array}{l}\text { EF value more than } 2 \\
\text { signifies anthropogenic } \\
\text { contribution in the } \\
\text { origin of heavy metals } \\
E F<2 \text { Deficiency to } \\
\text { mineral enrichment } \\
2<E F<5 \text { Moderate } \\
\text { Enrichment } \\
E F>5 \text { High Enrichment }\end{array}$ & $\begin{array}{l}\text { Aluminium is generally } \\
\text { used as reference element }\end{array}$ & {$[238,242]$} \\
\hline $\begin{array}{l}\text { Sediment } \\
\text { Pollution Index } \\
\text { (SPI) }\end{array}$ & $\begin{array}{l}\text { Ratio of a linear } \\
\text { combination of EF to } \\
\text { the sum of the } \\
\text { individual weights of all } \\
\text { heavy metals } \\
\text { (e.g. Cr and } \mathrm{Zn} \text { is } \\
\text { assigned a weight of } 1 \text { ) }\end{array}$ & $\begin{array}{l}\text { SPI value exceeding } 20 \\
\text { are classified to be toxic }\end{array}$ & $\begin{array}{l}\mathrm{SPI} \text { accounts the type of } \\
\text { metal toxicity that is not } \\
\text { accounted in } \mathrm{EF}\end{array}$ & {$[76,239]$} \\
\hline $\begin{array}{l}\text { Pollution Load } \\
\text { Index (PLI) }\end{array}$ & $\begin{array}{l}\text { PLI evaluates of the } \\
\text { enrichment factor of } \\
\text { various metallic } \\
\text { elements using the } \\
\text { expression: } \\
\left(\mathrm{EF}_{1} . \mathrm{EF}_{2} \ldots \mathrm{EF}_{\mathrm{n}}\right)^{1 / \mathrm{n}}\end{array}$ & $\begin{array}{l}\text { Sediment is polluted if } \\
\text { PLI is higher than } 1\end{array}$ & $\begin{array}{l}\mathrm{n} \text { is the number of heavy } \\
\text { metals taken into } \\
\text { consideration }\end{array}$ & [240] \\
\hline $\begin{array}{l}\text { Geo- } \\
\text { accumulation } \\
\text { Index (lgeo })\end{array}$ & $\begin{array}{l}\text { Igeo assess the } \\
\text { contamination of } \\
\text { sediments by heavy } \\
\text { metals using the } \\
\text { expression: } \\
\text { Igeo }=\log _{2}\left(\frac{C_{n}}{1.5 x B_{n}}\right) \\
C_{n} \text { is the measured } \\
\text { concentration of the } \\
\text { metal " } n \text { ", within the } \\
\text { sediment or size } \\
\text { fraction. } B_{n} \text { represents } \\
\text { the background } \\
\text { concentration of the } \\
\text { metal. }\end{array}$ & $\begin{array}{l}\text { Igeo }_{\text {ge }}<0 \text { Uncontaminated } \\
\text { Igeo } 0-3 \\
\text { Uncontaminated to } \\
\text { Moderately } \\
\text { Contaminated } \\
\text { Igeo }>3 \text { Strongly } \\
\text { Contaminated }\end{array}$ & $\begin{array}{l}\text { A factor of } 1.5 \text { is } \\
\text { considered to minimize } \\
\text { the impact of possible } \\
\text { changes caused by } \\
\text { lithological variations }\end{array}$ & [241] \\
\hline
\end{tabular}

